\title{
Corn Silage Management: Effects of Hybrid, Chop Length, and Mechanical Processing on Digestion and Energy Content \\ L. M. Johnson, ${ }^{\star}$ J. H. Harrison, ${ }^{\star}$ D. Davidson, ${ }^{*}$ \\ W. C. Mahanna, $\dagger$ and K. Shinnersł \\ *Department of Animal Sciences, Washington \\ State University, Puyallup, 98371 \\ †Pioneer Hi-Bred International, Des Moines, IA, 50131 \\ ‡Department of Biological System Engineering, \\ University of Wisconsin, Madison, 53706
}

\section{ABSTRACT}

Two experiments were conducted to evaluate the effects of chop length and mechanical processing of two hybrids of whole plant corn on digestion and energy content of the total mixed ration (TMR). The experimental designs in experiments 1 and 2 were $6 \times 6$ and $4 \times$ 4 Latin squares, respectively. In the first experiment, Pioneer hybrid 3845 was harvested at three theoretical lengths of cut: 11.1, 27.8, and $39.7 \mathrm{~mm}$. At each chop length, corn was harvested with and without mechanical processing using a John Deere 5830 harvester with an onboard kernel processor. In the second experiment, Pioneer hybrid Quanta was harvested at two theoretical lengths of cut: 27.8 and $39.7 \mathrm{~mm}$, with and without mechanical processing. In both experiments, the increase in the theoretical length of cut of corn silage increased the average length of cut and tended to increase the percentage of particles greater than $19 \mathrm{~mm}$ and lower the percentage of particles between 8 and 19 $\mathrm{mm}$. In experiment 1 , apparent total tract dry matter, organic matter, and neutral detergent fiber (NDF) digestibilities were lower for cows fed diets containing corn silage harvested at a short chop length $(11.1 \mathrm{~mm})$ than for corn silage harvested at a long chop length $(39.7 \mathrm{~mm})$. The lower total tract digestibility of nutrients may have contributed to the lower TDN, metabolizable energy (percentage of digestible energy), and $\mathrm{NE}_{\mathrm{L}}$ concentration of diets containing the short chop length corn silage (experiment 1 ). In experiment 2 , total tract starch digestibility was greater for cows fed medium chop $(27.8 \mathrm{~mm})$ corn silage diets, and total tract NDF digestibility was greater for cows fed long chop (39.7 $\mathrm{mm}$ ) corn silage diets. The opposing effect of total tract starch and fiber digestibilities between chop lengths may have contributed to the lack of difference in energy

Received February 14, 2001

Accepted August 2, 2002.

Corresponding author: Joe Harrison; e-mail: harrison@puyallup. wsu.edu. content of the diets in experiment 2 . The TDN and $\mathrm{NE}_{\mathrm{L}}$ concentrations of the processed corn silage diets were greater than the unprocessed corn silage diets in experiment 1 . The increase in energy concentration for the processed corn silage diet was due to greater total tract digestibility of organic matter and ether extract. Total tract starch digestibility was greater, and total tract NDF digestibility was lower for cows fed processed corn silage diets than unprocessed corn silage diets in experiment 2. The opposing effect of total tract starch and fiber digestibilities between processed and unprocessed corn silage may have contributed to the lack of difference in energy content of the diets.

(Key words: corn silage, mechanical processing, chop length)

Abbreviation key: ADICP = acid detergent insoluble CP, ALC = average length-of-cut, $\mathbf{D E}=$ digestible energy, $\mathbf{M E}=$ metabolizable energy, $\mathbf{M U N}=$ milk urea N, NAN = nonammonia $\mathbf{N}, \mathbf{N A N M N}=$ nonammonia nonmicrobial N, NDICP = neutral detergent insoluble $\mathrm{CP}, \mathbf{N F C}=$ nonfiber carbohydrates, $\mathbf{T L C}=$ theoretical length of cut.

\section{INTRODUCTION}

During the past decade, there has been rapid adoption by dairy producers in the United States to harvest whole plant corn with forage harvesters equipped with kernel processing units. Mechanical processing has been reported to reduce particle size of corn silage 15 to $30 \%$ and increase the machine energy requirement by approximately 7 to $15 \%$ (Schurig and Rodel, 1993; Roberge et al., 1998) when the theoretical length of cut (TLC) was similar between the processed and unprocessed corn silage treatments. Many professionals have recommended an increased TLC when corn silage is processed before ensiling. The increased TLC of corn silage reduces the increase in power requirements due to mechanical processing. Also, increasing the TLC of processed corn silage is thought to maintain the 'effectiveness' of the fiber in corn silage, while fracturing the 
corn kernels and crushing the corn stover. Fracturing the corn kernels in corn silage improved starch digestibility (Rojas-Bourrillon et al., 1987; Doggett, 1998; Andrae, 2000; Bal et al., 2000; Weiss and Wyatt, 2000; Johnson, 2002a), and crushing and shearing the stover fraction improved NDF digestibility in some studies (Doggett, 1998; Andrae, 2000; Johnson, 2002b).

It is not uncommon to hear recommendations to harvest corn silage at a TLC as great as 25.4 to $38.1 \mathrm{~mm}$. However, there is limited research published to determine how the long chop length, with and without mechanical processing, will impact ruminal and total tract digestion, nitrogen metabolism, energy content of the diet, or performance characteristics of lactating dairy cattle. Limited research has also been published on how the long chop length, with and without mechanical processing, will impact silage fermentation characteristics and aerobic stability.

Studies that have evaluated the effects of chop length or chop length and processing interactions on performance characteristics, chewing activity, and digestibility have reported varying results. Results from a recently published study (Bal et al., 2000) indicated that cows fed diets containing processed corn silage harvested at three chop lengths $(0.95,1.45$, and $1.90 \mathrm{~cm})$ had increased DMI, BW, milk production, and milk fat concentration compared with cows fed diets containing unprocessed corn silage harvested at $0.95 \mathrm{~cm}$. The increase in milk production for cows fed processed corn silage-based diets could be related to increased ruminal and total tract starch digestibility compared with cows fed unprocessed corn silage-based diets (Bal et al., 2000). However, chop length did not affect milk and FCM production (Bal et al., 2000). The major effect of corn silage chop length, in the study of Bal et al. (2000), was that cows fed diets containing corn silage harvested at a short chop $(0.95 \mathrm{~cm})$ tended to have depressed fiber digestibility compared to cows fed diets containing long chop $(1.90 \mathrm{~cm})$ corn silage. Other studies have reported an improvement in milk production when chop length of corn silage was altered. Clark and Armentano (1999) reported a linear increase in milk, fat, and protein yields as mean particle size of corn silage decreased from 6.53 to $2.57 \mathrm{~mm}$. Schurig and Rodel (1993) reported an increase in DMI, milk production, and milk fat and protein concentrations when cows were fed diets containing processed corn silage harvested at a short chop length (TLC $=4 \mathrm{~mm}$ ) compared to processed and unprocessed corn silage harvested at a medium chop length $(8 \mathrm{~mm})$. However, some studies have reported no difference in milk production (Stockdale and Beavis, 1994; Clark and Armentano, 1999), chewing behavior (Clark and Armentano, 1999), or total tract digestibility
(Stockdale and Beavis, 1994) for cows fed diets containing corn silage harvested at different chop lengths.

The majority of the data published in the literature used corn silage harvested at a TLC of $\leq 19 \mathrm{~mm}$. Therefore, in this study a range of chop lengths (11 to 40 $\mathrm{mm}$ ) was selected to evaluate current recommendations of harvesting corn silage at longer chop lengths with mechanical processing. The primary objective of this study was to evaluate the effects of hybrid, chop length, and mechanical processing of corn silage on ruminal and total tract digestion and energy content of the TMR. The secondary objective was to evaluate the effects of hybrid, chop length, and mechanical processing of corn silage on energy requirements, nitrogen metabolism, ruminal fermentation characteristics, and performance characteristics. Pack density and dry matter recovery of the corn silage treatments were also evaluated.

\section{MATERIALS AND METHODS}

\section{Cows, Diets, and Experimental Design}

Two total collection digestion and metabolism studies were conducted using ruminally and duodenally cannulated lactating Holstein cows. In experiment 1, six ruminally and duodenally cannulated lactating Holstein cows were used in a $6 \times 6$ Latin square design, and in experiment 2 , four ruminally and duodenally cannulated lactating Holstein cows were used in a $4 \times 4$ Latin square design. Experimental periods were $14 \mathrm{~d}$; the first $10 \mathrm{~d}$ were for adjustment, and the last $4 \mathrm{~d}$ were for collection of samples and data. Ruminal cannulae (Bar Diamond, Inc., Parma, ID) had a 10.2-cm center diameter. Cows were fitted with T-shaped duodenal cannulas (Bar Diamond, Inc.). All cows used in these experiments were multiparous, and some cows were used in more than one experiment.

Cows were individually fed with Calan headgates (American Calan, Inc., Northwood, NH) in a free-stall barn during the adaptation periods. Cows were fed enough TMR twice daily (1000 and $1600 \mathrm{~h}$ ) to allow $10 \%$ orts. In all experiments, cows were fed a similar proportion of corn silage ( $26.8 \%$ of diet DM), alfalfa hay (13.2\% of diet DM), whole cottonseed (13.6\% of diet $\mathrm{DM})$, and grain mix (46.4\% of diet DM) (Table 1). The TMR was mixed in a Calan data ranger (American Calan, Inc., Northwood, NH). All cows were administered bST (Posilac, Monsanto Company, St. Louis, MO) at 2wk intervals during the study.

Experiment 1. Cows averaged 217 DIM at the beginning of the experiment. Pioneer hybrid 3845 (Pioneer Hi-Bred Int., Inc., Johnston, IA) corn silage was harvested during the 1998 growing season at three TLC. The three TLC for the corn silage were $11.1 \mathrm{~mm}$ (harvester set with five rows of knives and a 10-tooth 
Table 1. Ingredients of the diets and treatments administered in experiments 1 and 2 (DM basis).

\begin{tabular}{|c|c|c|}
\hline \multirow[b]{2}{*}{ Ingredient } & \multicolumn{2}{|c|}{ Experiment } \\
\hline & 1 & 2 \\
\hline & $\longrightarrow$ & \\
\hline Corn silage & 26.8 & 26.8 \\
\hline Whole cottonseed & 13.6 & 13.6 \\
\hline Alfalfa hay & 13.2 & 13.2 \\
\hline Barley grain, steam rolled & 14.0 & 14.0 \\
\hline Corn grain, steam rolled & 14.0 & 14.0 \\
\hline Soybean meal ( $47 \% \mathrm{CP}$, expeller processed) & 5.1 & 5.1 \\
\hline Wheat millrun & 4.2 & 4.2 \\
\hline Prolak $^{1}$ & 2.3 & 2.3 \\
\hline Beet pulp & 2.4 & 2.4 \\
\hline Sodium bicarbonate & 1.85 & 1.85 \\
\hline Molasses & 0.84 & 0.84 \\
\hline Limestone & 0.75 & 0.75 \\
\hline Salt & 0.35 & 0.35 \\
\hline Biofos $^{2}$ & 0.30 & 0.30 \\
\hline Mg oxide & 0.19 & 0.19 \\
\hline WSU mineral premix ${ }^{3}$ & 0.12 & 0.12 \\
\hline
\end{tabular}

${ }^{1}$ Prolak - H. J. Baker \& Bro., Inc., (Stamford, Conneticut).

${ }^{2}$ Biofos - IMC, (Lake Forest, Illinois).

${ }^{3} \mathrm{WSU}$ mineral premix - $5863 \mathrm{kIU} / \mathrm{kg}$ of vitamin A, $2640 \mathrm{kIU} / \mathrm{kg}$ of vitamin D, 14,674 IU/kg of vitamin E, $220 \mathrm{ppm}$ of $\mathrm{Co}, 16,500 \mathrm{ppm}$ of $\mathrm{Cu}, 660 \mathrm{ppm}$ of $\mathrm{Fe}, 880 \mathrm{ppm}$ of I, 44,000 ppm of $\mathrm{Mn}, 220 \mathrm{ppm}$ of Se, 44,000 ppm of Zn.

sprocket; short), $27.8 \mathrm{~mm}$ (harvester set with two rows of knives and a 10 tooth sprocket; medium), and 39.7 $\mathrm{mm}$ (harvester set with two rows of knives and a 16tooth sprocket; long).

Experiment 2. Cows averaged $128 \mathrm{DIM}$ at the beginning of the experiment. Pioneer hybrid Quanta (Pioneer Hi-Bred Int., Inc.) corn silage was harvested during the 1998 growing season at two chop lengths. The TLC for the corn silage were $27.8 \mathrm{~mm}$ (harvester set with two rows of knives and a 10-tooth sprocket; medium) and $39.7 \mathrm{~mm}$ (harvester set with two rows of knives and a 16-tooth sprocket; long).

\section{Corn Silage and TMR}

Corn silage was harvested with a self-propelled John Deere 5830 harvester (with a kernel processing unit) at a ground speed between 3.2 and $4.0 \mathrm{~km} / \mathrm{h}$. The processing equipment was fully active (two counter-rotating rolls positioned between the cutterhead and blower with their axis of rotation parallel to the cutterhead). At each chop length, corn silage was harvested with the kernel processing rolls set $1 \mathrm{~mm}$ apart (processed) and with the kernel processing rolls set $15.9 \mathrm{~mm}$ apart (unprocessed). Corn silage, in both experiments, was harvested at two-thirds milk line and inoculated at the harvester with Pioneer 1132 (Pioneer Hi-Bred Int., Inc.) inoculant.
Two hybrids of corn silage were chosen (experiment 1 - Pioneer hybrid 3845 and experiment $2-$ Pioneer hybrid Quanta) to evaluate the effects of chop length and processing of whole plant corn on digestion and energy content of the TMR. Hybrid Quanta is a flint corn, and hybrid 3845 is a dent corn. Hybrid Quanta tends to have higher DM and starch content at the same maturity as hybrid 3845 . Flint corn also tends to have a greater percentage of vitreous starch than dent corn. Vitreous starch tends to be less digestible because it contains starch that is embedded in a protein matrix (Kortarski et al., 1992).

Corn silage was stored in 122 -cm high $\times 122$-cm diameter tubes that were lined with $\mathrm{Ag} \mathrm{Bag}$ (Ag Bag International, Ltd., Warrenton, OR) bale bag material. Corn silage was packed by manually stomping whole plant corn as it was added. Plywood was placed on the top of each tube, and $182 \mathrm{~kg}$ of weight was added to the top to provide packing pressure. Each tube held approximately $455 \mathrm{~kg}$ of corn silage on an as-is basis.

\section{Sample Collection}

Cows were housed in a metabolism barn during the collection period (d 11 to 14). Body weights were recorded at the beginning (before entering the metabolism barn) and end (before entering the free-stall barn) of the collection period. Descriptions of the handling and collection of TMR, orts, corn silage, alfalfa hay, whole cottonseed, grain mix, urine, and feces were discussed in Johnson et al. (2002b). Descriptions of labeling grass silage with $\mathrm{YbCl}_{3} \cdot 6 \mathrm{H}_{2} \mathrm{O}$, dosing $\mathrm{YbCl}_{3} \cdot 6 \mathrm{H}_{2} \mathrm{O}$ labeled grass silage, and sampling methods of duodenal fluid were described in Johnson et al. (2002b). Descriptions of the collection and handling of rumen fluid and milk samples were described in Johnson et al. (2002c).

\section{Sample Preparation and Analysis}

Sample preparation of TMR, orts, corn silage, alfalfa hay, whole cottonseed, grain mix, feces, and duodenal samples were described in Johnson et al. (2002a). Corn silage was prepared and analyzed for VFA, lactate, ethanol, and $\mathrm{pH}$ as described in Johnson et al. (2002a). Wet postensiled corn silage, TMR, and orts were sampled once each period for each treatment and analyzed for particle size and distribution using NASCO's Penn State Forage Particle Separator (NASCO, Fort Atkinson, WI). Wet preensiled corn silage was sampled twice during harvest and analyzed for particle size and distribution using NASCO's Penn State Forage Particle Separator.

Dried corn silage, alfalfa hay, whole cottonseed, grain mix, TMR, orts, duodenal, and fecal samples were 
ground through a 1-mm screen using a Wiley mill (Arthur H. Thomas, Philadelphia, PA) and analyzed for DM and ash (AOAC, 1990). Corn silage, TMR, alfalfa hay, whole cottonseed, and grain mix were analyzed for CP (AOAC, 1990), NDF with sulfite (Van Soest et al., 1991), ADF (Goering and Van Soest, 1970), lignin (Goering and Van Soest, 1970), ether extract (AOAC, 1990), and starch (modified starch procedure of Holm et al., 1986; described in Johnson et al., 2002a). Corn silage and TMR were analyzed for acid detergent insoluble CP (ADICP; Goering and Van Soest, 1970) and neutral detergent insoluble CP (NDICP; Goering and Van Soest, 1970). Pre- and postensiled corn kernels and cobs were analyzed for DM (AOAC, 1990). Preensiled stalk, leaves, and husk were analyzed for DM (AOAC, 1990). Postensiled corn kernels were separated from corn stover, and estimates were made of the percentage of whole intact vs. damaged corn kernels present based on the weight of each fraction. Orts were analyzed for CP (AOAC, 1990), NDF with sulfite (Van Soest, 1991), ADF (Goering and Van Soest, 1970), and starch (modified starch procedure of Holm et al., 1986; described in Johnson et al., 2002a). Hemicellulose, cellulose, and nonfiber carbohydrate (NFC) concentrations of the corn silage, TMR, and orts were calculated according to equations described in Johnson et al. (2002a).

Separate aliquots containing a wet sample of the homogenized duodenal digesta, feces, and urine were analyzed for total N (AOAC, 1990). Wet samples of duodenal fluid and rumen fluid collected 2 and $6 \mathrm{~h}$ after feeding were analyzed for ammonia N (AOAC, 1990). Wet samples of rumen fluid were analyzed for VFA and lactate as described in Johnson et al. (2002c). Dried fecal and duodenal samples were analyzed for NDF with sulfite (Van Soest, 1991) and starch (modified starch procedure of Holm, et al., 1986; described in Johnson et al., 2002a). Dried duodenal samples were analyzed for purine concentrations (Zinn and Owens, 1986) and $\mathrm{Yb}$ concentration by the inductively coupled plasma (ICP) spectroscopy procedure (Fassel, 1978) using an extraction procedure described by Williams et al. (1962).

Energy on dried and ground samples of corn silage, TMR, orts, and feces was determined by combustion in an adiabatic oxygen bomb calorimeter (Adiabatic Calorimeter, Parr Instrument Co., Moline, IL). The equations used to estimate urinary energy ( $\mathrm{Kcal} / \mathrm{kg})$, methane energy, measured TDN (estimated from digestible $\mathrm{CP}$, digestible NDF, digestible nonfiber carbohydrates, and digestible ether extract), $\mathrm{NE}_{\mathrm{L}}$, and calculated TDN (estimated from DE) were described in Johnson et al. (2002b).

Thawed milk samples were analyzed for fat and CP concentrations using an infrared analyzer (DHI Labo-
Table 2. Physical characteristics of the corn grain, cob, stalk, leaves, and husk of preensiled corn silage in experiments 1 and 2 (DM basis).

\begin{tabular}{lrr}
\hline & \multicolumn{2}{c}{ Experiment } \\
\cline { 2 - 3 } Physical & 1 & \multicolumn{1}{c}{2} \\
\cline { 2 - 3 } & & \\
Whole corn DM & 32.0 & 37.8 \\
Kernel DM & 50.0 & 64.5 \\
Cob DM & 33.7 & 41.8 \\
Stalk DM & 19.6 & 22.6 \\
Leaf DM & 24.9 & 41.1 \\
Husk DM & 25.8 & 37.4 \\
Kernel, \% of DM & 46.1 & 52.5 \\
Cob, \% of DM & 11.1 & 8.4 \\
Stalk, \% of DM & 22.8 & 20.6 \\
Leaves, \% of DM & 14.0 & 43.7 \\
Husk, \% of DM & 6.0 & 4.8 \\
\hline
\end{tabular}

ratory, Burlington, WA). Milk samples that had been frozen at $-20^{\circ} \mathrm{C}$, were analyzed for $\mathrm{N}$ (AOAC, 1990), casein N (AOAC, 1990), and milk urea N (MUN; enzymatic in vitro assay for quantitative determination of urea, Roche Diagnostics, 1998). The initial weights of corn were put into the silo, spoilage removed, and silage fed recorded. Dry matter recovery and amount of feedable silage were estimated from measures obtained and respective DM. Pack density estimates were measured as described in Johnson et al. (2002a).

\section{Statistical Analysis}

The model for each experiment (experiments 1 and 2) was;

$$
\mathrm{Y}_{\mathrm{ijk} \mathrm{l}}=\mu+\mathrm{C}_{\mathrm{i}}+\mathrm{P}_{\mathrm{j}}+\mathrm{M}_{\mathrm{k}}+\mathrm{K}_{\mathrm{l}}+(\mathrm{M} \times \mathrm{K})_{\mathrm{kl}}+\mathrm{E}_{\mathrm{ijkl}}
$$

where $\mu$ overall mean, $\mathrm{C}_{\mathrm{i}}=$ cow effect, $\mathrm{P}_{\mathrm{j}}=$ period effect, $\mathrm{M}_{\mathrm{k}}=$ chop length effect, $\mathrm{K}_{\mathrm{l}}=$ kernel processing effect $(\mathrm{l}=1$ to 2$),(\mathrm{M} \times \mathrm{K})_{\mathrm{kl}}$ = interaction effect of $\mathrm{M}_{\mathrm{k}}$ and $\mathrm{K}_{\mathrm{l}}$, and $\mathrm{E}_{\mathrm{ijkl}}=$ error term. Treatment means were separated using the least significant difference test when a significant treatment effect $(P<0.05)$ or trend $(P<0.10)$ was observed (SAS, 1988).

\section{RESULTS AND DISCUSSION}

\section{Physical and Chemical Characteristics of Corn Silage and TMR}

Preensiled whole plant corn (five plants per treatment) was separated into kernels, cob, stalk, leaves, and husk, and the DM concentration and percentage of each fraction on a DM basis are reported in Table 2 (data not statistically analyzed). Hybrid Quanta had drier kernels, cob, stalk, leaves, and husk than hybrid 3845 because hybrid Quanta (37.8\%) was harvested at 
Table 3. Chemical composition and physical characteristics of the individual ingredients fed in experiment 1 for processed (proc) and unprocessed (unproc) corn silage treatments (DM basis).

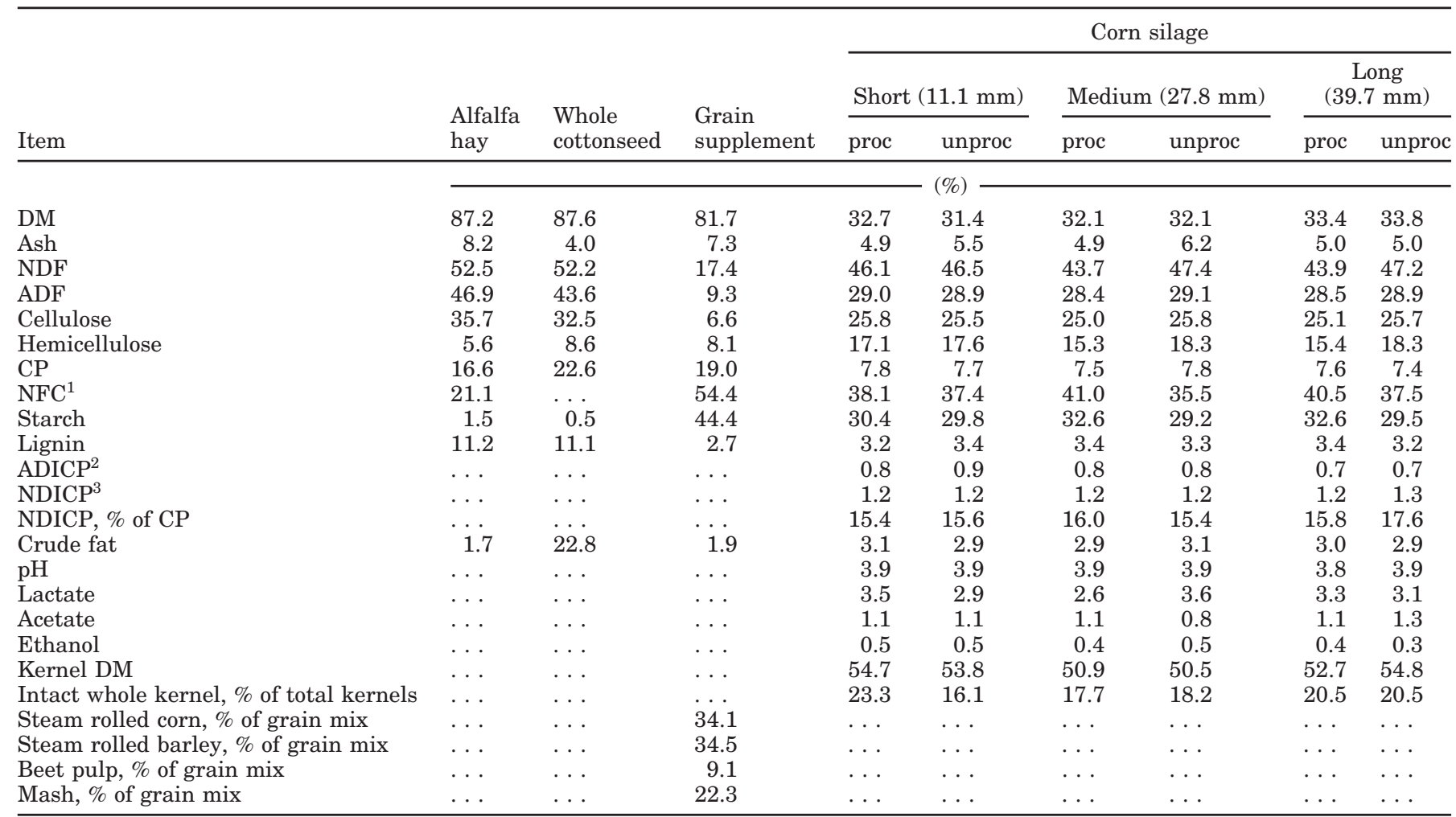

${ }^{1} \mathrm{NFC}-$ Nonfiber carbohydrate $=100-(\mathrm{NDF}+\mathrm{CP}+$ ether extract + ash $)$.

${ }^{2} \mathrm{ADICP}$ - Acid detergent insoluble CP.

${ }^{3} \mathrm{NDICP}$ - Neutral detergent insoluble CP.

a higher whole plant DM than hybrid 3845 (32.0\%). Hybrid Quanta also had a greater proportion of the whole plant corn (DM basis) that was kernels than hybrid 3845 .

Processing affected some of the chemical characteristics of corn silage in experiments 1 and 2 (Tables 3 and 4 ; data not statistically analyzed). The concentrations of NDF and hemicellulose were greater for unprocessed corn silage than processed corn silage at the medium and long chop lengths in experiment 1 , and similar between processed and unprocessed corn silage in experiment 2 . The differences reported in experiment 1 should not be due to harvesting and storage techniques because similar practices were used between processed and unprocessed corn silage treatments at all chop lengths. Others have reported greater NDF concentrations for unprocessed corn silage compared with processed corn silage (Rojas-Bourrillon et al., 1987; Johnson, 1996; Doggett et al., 1998; Bal et al., 2000; Johnson et al., 2002a). However, at other times, no difference (Bal et al., 2000) or lower NDF concentrations for unprocessed compared with processed corn silage (Weiss and Wyatt, 2000) were reported.
Nonfiber carbohydrate concentrations were greater for processed corn silage in four out of five comparisons of processed and unprocessed corn silage, and starch concentration was greater in five out of five comparisons (Tables 3 and 4). At the medium chop length, in both experiments, and at the long chop length, in experiment 1 , the difference in NFC concentration between processed and unprocessed corn silage was substantial (range: 2.4 to 5.5 percentage unit difference). In this study, it appears that processing corn silage at the longer chop lengths (27.8 and $39.7 \mathrm{~mm}$ ) tended to alter the physical characteristics of the corn silage before ensiling and enhanced formation of fractions measured in the NFC equation during ensiling. The increased NFC fractions for processed corn silage at the longer chop lengths ( 27.8 and $39.7 \mathrm{~mm}$ ) must have been component other than fermentation acids (lactate, acetate, and ethanol) because the fermentation acids did not tend to differ greatly between processed and unprocessed corn silage.

Hybrid also influenced the chemical characteristics of the corn silage (Tables 3 and 4). Hybrid Quanta corn silage had a greater DM concentration (38.9 vs. $32.5 \%$ ) 
Table 4. Chemical composition and physical characteristics of the individual ingredients fed in experiment 2 for processed (proc) and unprocessed (unproc) treatments (DM basis).

\begin{tabular}{|c|c|c|c|c|c|c|c|}
\hline \multirow[b]{2}{*}{ Item } & \multirow{2}{*}{$\begin{array}{l}\text { Alfalfa } \\
\text { hay }\end{array}$} & \multirow{2}{*}{$\begin{array}{l}\text { Whole } \\
\text { cottonseed }\end{array}$} & \multirow{2}{*}{$\begin{array}{l}\text { Grain } \\
\text { supplement }\end{array}$} & \multicolumn{4}{|c|}{ Corn silage } \\
\hline & & & & proc & uproc & proc & unproc \\
\hline & & & & $\%$ & 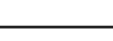 & 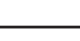 & 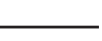 \\
\hline DM & 89.0 & 88.9 & 85.3 & 39.3 & 37.7 & 40.1 & 38.5 \\
\hline Ash & 7.0 & 3.9 & 6.9 & 3.7 & 4.2 & 4.0 & 3.6 \\
\hline NDF & 57.3 & 49.2 & 16.0 & 41.1 & 42.8 & 44.4 & 44.3 \\
\hline Hemicellulose & 7.9 & 12.9 & 8.8 & 17.0 & 16.5 & 19.2 & 18.7 \\
\hline CP & 15.3 & 24.0 & 16.6 & 8.0 & 8.1 & 8.0 & 8.1 \\
\hline $\mathrm{NFC}^{1}$ & 18.9 & 2.8 & 57.7 & 44.3 & 41.9 & 40.5 & 41.0 \\
\hline Starch & 1.4 & 0.8 & 45.2 & 34.8 & 33.9 & 34.2 & 32.2 \\
\hline Lignin & 10.4 & 11.2 & 0.7 & 3.1 & 3.2 & 3.1 & 3.2 \\
\hline $\mathrm{ADICP}^{2}$ & 0. & $\ldots$ & $\ldots$ & 0.7 & 0.8 & 0.8 & 0.8 \\
\hline $\mathrm{NDICP}^{3}$ & $\cdots$ & $\cdots$ & $\cdots$ & 1.2 & 0.9 & 1.1 & 1.1 \\
\hline Acetate & $\ldots$ & $\ldots$ & $\ldots$ & 1.0 & 1.1 & 1.2 & 1.6 \\
\hline Ethanol & $\ldots$ & $\ldots$ & $\ldots$ & 0.5 & 0.6 & 0.4 & 0.5 \\
\hline Kernel DM & $\ldots$ & $\ldots$ & $\ldots$ & 54.0 & 55.0 & 53.7 & 54.5 \\
\hline Intact whole kernel, $\%$ of total kernels & $\cdots$ & $\ldots$ & $\cdots$ & 5.3 & 8.3 & 2.8 & 8.5 \\
\hline Steam rolled corn, \% of grain mix & $\cdots$ & $\ldots$ & 31.7 & $\ldots$ & $\ldots$ & $\ldots$ & $\ldots$ \\
\hline Steam rolled barley, $\%$ of grain mix & $\cdots$ & $\ldots$ & 34.0 & $\ldots$ & $\cdots$ & $\ldots$ & $\cdots$ \\
\hline Beet pulp, $\%$ of grain mix & $\ldots$ & $\ldots$ & 6.4 & $\ldots$ & $\ldots$ & $\ldots$ & $\ldots$ \\
\hline Mash, $\%$ of grain mix & $\ldots$ & $\ldots$ & 27.9 & $\ldots$ & $\ldots$ & $\ldots$ & $\ldots$ \\
\hline
\end{tabular}

${ }^{1} \mathrm{NFC}-$ Nonfiber carbohydrate $=100-(\mathrm{NDF}+\mathrm{CP}+$ ether extract + ash $)$.

${ }^{2} \mathrm{ADICP}$ - Acid detergent insoluble CP.

${ }^{3} \mathrm{NDICP}$ - Neutral detergent insoluble CP.

than hybrid 3845 (Tables 3 and 4). Hybrid Quanta also had lower concentrations of ash, ADF, cellulose, and NDICP (percentage of CP) and greater concentrations of starch and CP than hybrid 3845 (Tables 3 and 4). These results were similar to others (Johnson et al., 2002a).

In experiment 2, hybrid Quanta corn silage appeared to have translocation of water from the corn stover portion of the plant into the corn kernel during the ensiling and storage phases. The DM concentration of preensiled corn kernels was $64.5 \%$ (Table 2), and the postensiled DM concentration was 54.3\% (Table 4). However, this same trend did not occur with hybrid 3845 (experiment 1). The DM concentration of the preensiled corn kernels was 50\% (Table 2), and the DM concentration of the postensiled corn kernels was 53\% (Table 3). The reason for a lack of difference between pre- and postensiled DM concentrations for hybrid 3845 , in the current study, is unknown. Other data (Johnson et al., 2002a) have also reported trends of translocation of water from stover to kernels for hybrids 3845 and Quanta.

In experiment 1 , the percentage of intact, whole corn kernels tended to be slightly greater for corn silage harvested at long chop ( $\mathrm{TLC}=39.7 \mathrm{~mm}$ ) compared with corn silage harvested at medium chop $(\mathrm{TLC}=27.8 \mathrm{~mm}$; Table 3). However, in experiment 1, processing did not reduce the amount of intact corn kernels compared with unprocessed corn silage. In experiment 2 , the processed corn silage tended to have a lower percentage of intact corn kernels compared with the unprocessed corn silage (Table 4).

The chemical composition of the TMR fed in experiments 1 and 2 was reported in Tables 5 and 6, respectively. Forage NDF (percentage of total NDF; includes NDF from corn silage and alfalfa hay only) was greater for unprocessed corn silage at the medium and long chop lengths $(P<0.04)$ than processed corn silage in experiment 1 . In experiment $2, \mathrm{NDF}$ consumed as a percentage of DMI was lower $(P<0.006)$ and starch consumed as a percentage of DMI was greater $(P<0.04)$ for corn silage harvested at the medium chop length compared to long chop (TLC $=39.7 \mathrm{~mm}$; Table 6).

The actual nutrient concentrations consumed, as a percentage of DMI, were compared to nutrients offered in the original TMR. The actual NDF and ADF concentrations consumed, as a percentage of DMI, were lower for all treatments than the ADF and NDF concentra- 
Table 5. Chemical composition of the TMR fed in experiment 1 for processed (proc) and unprocessed (unproc) corn silage treatments (DM basis).

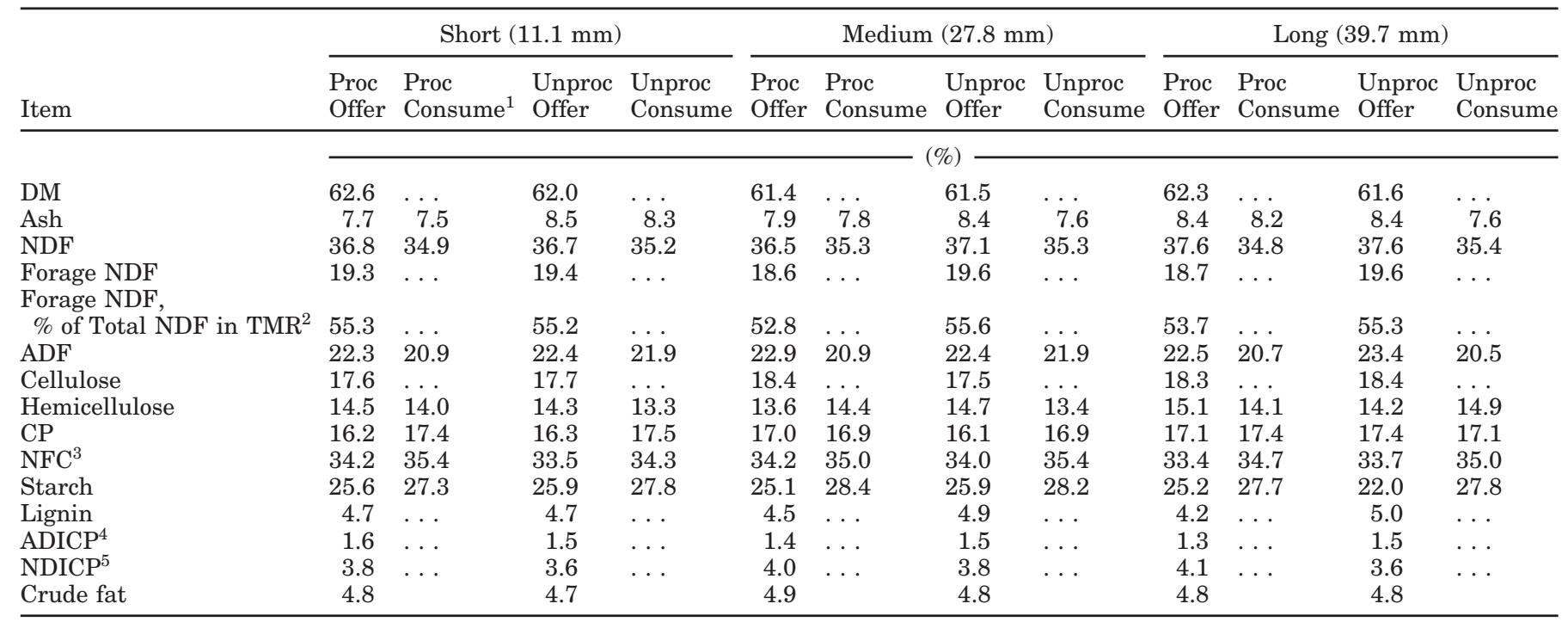

${ }^{1}$ Consume - The percentage of a nutrient present in the actual diet that was consumed [(Intake, $\left.\left.\mathrm{kg}-\mathrm{Refusal}, \mathrm{kg}\right) / \mathrm{DMI}, \mathrm{kg}\right] \mathrm{versus}$ the percentage of a nutrient in the original TMR.

${ }^{2}$ Forage NDF, \% of Total NDF in TMR - Unprocessed corn silage had greater NDF $(P<0.04)$ than processed corn silage at medium and long chop lengths.

${ }^{3} \mathrm{NFC}-$ Nonfiber carbohydrate $=100-(\mathrm{NDF}+\mathrm{CP}+$ ether extract + ash $)$.

${ }^{4} \mathrm{ADICP}$ - Acid detergent insoluble CP.

${ }^{5} \mathrm{NDICP}$ - Neutral detergent insoluble CP.

Table 6. Chemical composition of the TMR fed in experiment 2 for processed (proc) and unprocessed (unproc) corn silage treatments (DM basis).

\begin{tabular}{|c|c|c|c|c|c|c|c|c|}
\hline Item & \multicolumn{4}{|c|}{ Medium $(27.8 \mathrm{~mm})$} & \multicolumn{4}{|c|}{ Long (39.7 mm) } \\
\hline & & & & - & & & & \\
\hline $\mathrm{DM}$ & 65.4 & $\ldots$ & 65.1 & . & 66.2 & $\ldots$ & 64.2 & $\ldots$ \\
\hline Ash & 7.4 & 7.0 & 7.8 & 6.3 & 6.1 & 6.8 & 7.1 & 6.6 \\
\hline $\mathrm{NDF}^{2}$ & 36.4 & 33.1 & 37.8 & 32.9 & 35.8 & 34.3 & 36.7 & 34.7 \\
\hline $\mathrm{ADF}$ & 22.4 & 19.1 & 22.8 & 19.0 & 22.0 & 19.6 & 22.4 & 20.5 \\
\hline Cellulose & 18.3 & $\ldots$ & 18.4 & $\ldots$ & 17.2 & $\ldots$ & 17.4 & $\ldots$ \\
\hline Hemicellulose & 14.0 & 14.0 & 15.0 & 13.8 & 13.8 & 14.7 & 14.3 & 14.2 \\
\hline $\mathrm{CP}$ & 17.9 & 16.7 & 17.8 & 16.8 & 15.9 & 17.1 & 16.0 & 16.7 \\
\hline $\mathrm{NFC}^{3,4}$ & 36.5 & 38.2 & 37.2 & 39.0 & 35.0 & 36.6 & 35.0 & 36.8 \\
\hline Starch & 26.2 & 31.1 & 26.8 & 31.8 & 30.2 & 30.4 & 26.6 & 29.0 \\
\hline Lignin & 4.1 & $\ldots$ & 4.4 & $\ldots$ & 4.8 & $\ldots$ & 5.0 & $\ldots$ \\
\hline
\end{tabular}

\footnotetext{
${ }^{1}$ Consume - The percentage of a nutrient present in the actual diet that was consumed [(Intake, $\left.\left.\mathrm{kg}-\mathrm{Refusal}, \mathrm{kg}\right) / \mathrm{DMI}, \mathrm{kg}\right] \mathrm{versus}$ the percentage of a nutrient in the original TMR.

${ }^{2} \mathrm{NDF}$ consumed as a percentage of DMI was lower for medium chop length corn silage $(P<0.006)$, and starch consumed as a percent of DMI was greater for medium chop length corn silage $(P<0.04)$.

${ }^{3} \mathrm{NFC}-$ Nonfiber carbohydrate $=100-(\mathrm{NDF}+\mathrm{CP}+$ ether extract + ash $)$.

${ }^{4} \mathrm{NFC}$ consumed as a percentage of DMI was greater $(P<0.004)$ for corn silage harvested at the medium chop length.

${ }^{5} \mathrm{ADICP}$ - Acid detergent insoluble CP.

${ }^{6} \mathrm{NDICP}$ - Neutral detergent insoluble CP.
} 
Table 7. Penn State Forage Particle Separator DM distribution data for preensiled and postensiled corn silage in experiments 1 and 2.

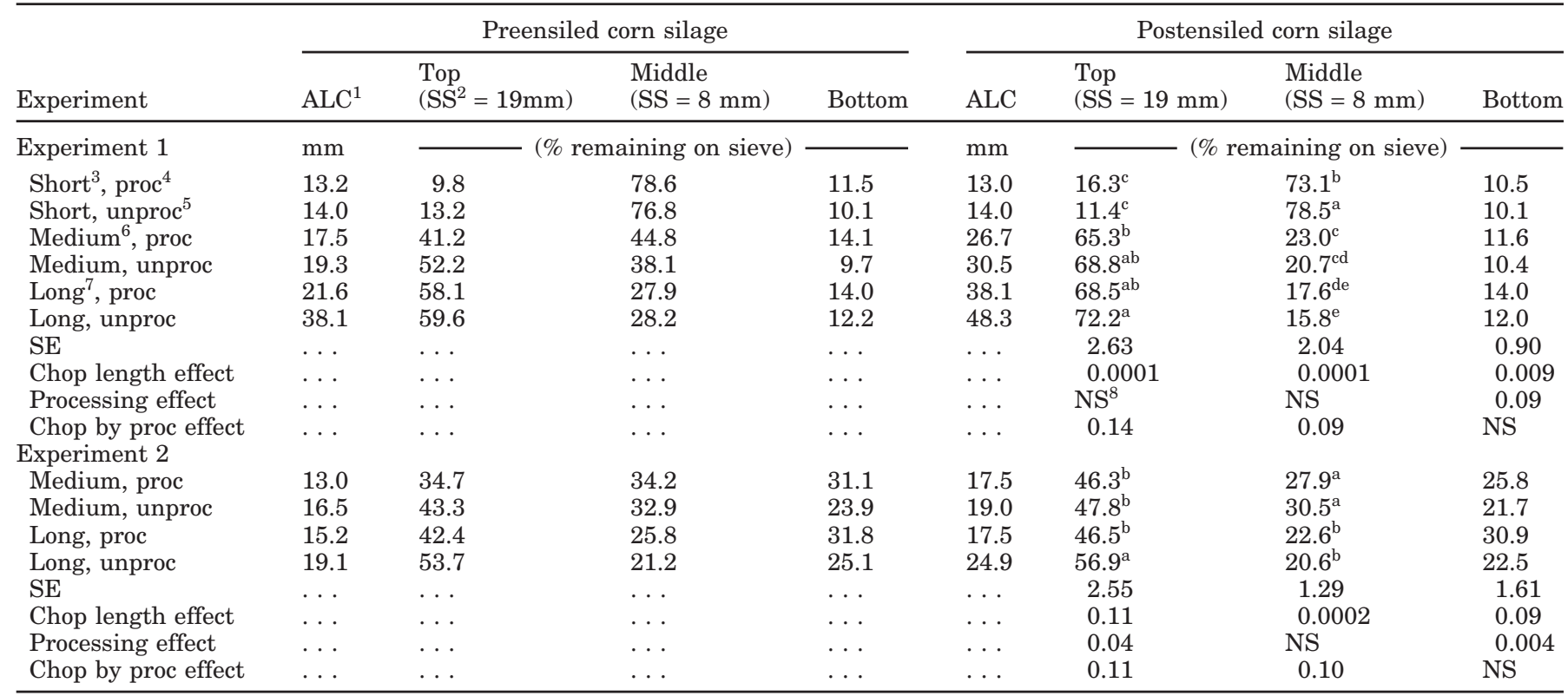

\footnotetext{
${ }^{1} \mathrm{ALC}=$ Average length-of-cut. Determination made using Weibull paper provided in NASCO's ${ }^{\circledR}$ Penn State forage particle separator direction packet. Average particle length (X-axis) estimated by interpolation from the $50 \%$ mark on the Y axis (cumulative \% undersized).

${ }^{2} \mathrm{SS}=$ Screen size.

${ }^{3}$ Short - Corn silage was harvested at a TLC of $11.1 \mathrm{~mm}$.

${ }^{4}$ Proc - Corn silage was harvested with a 5830 John Deere harvester with kernel processing rolls set $1 \mathrm{~mm}$ apart.

${ }^{5}$ Unproc - Corn silage was harvested with a 5830 John Deere harvester with kernel processing rolls set $15.9 \mathrm{~mm}$ apart.

${ }^{6}$ Medium - Corn silage was harvested at a TLC of $27.8 \mathrm{~mm}$.

${ }^{7}$ Long - Corn silage was harvested at a TLC of $39.7 \mathrm{~mm}$.

${ }^{8} \mathrm{NS}-P>0.10$.
}

tions offered in the TMR (Tables 5 and 6). Starch and NFC consumed, as a percentage of DMI, were greater for all treatments (except hybrid Quanta, long chop, processed TMR) than the starch and NFC concentrations in the TMR (Tables 5 and 6 ). These results suggest that sorting of the TMR occurred. The particles in the TMR with greater NDF and ADF concentrations were sorted and left in the ort, and particles containing starch and NFC were sorted and consumed by the cow. However, within an experiment and chop length, the TMR containing processed and unprocessed corn silages had similar concentrations (within 1.5 percentage units) of NDF and starch consumed as a percentage of DMI (Tables 5 and 6). Therefore, the concentration of fiber and starch that was actually consumed between TMR containing processed and unprocessed corn silage was similar.

\section{Particle Size and Distribution}

Corn silage. Pre- and postensiled whole plant corn was separated with the Penn State Forage Particle Separator (Table 7) to determine whether storage and unloading of the corn silage prior to feedout altered parti- cle size or distribution. In experiment 1 , preensiled whole plant corn had a lower average length-of-cut (ALC) and percentage of particles remaining on the top sieve of Penn State Forage Particle Separator than postensiled corn silage at the medium and long chop lengths (Table 7). In experiment 2, the preensiled whole plant corn also had a lower ALC and percentage of particles remaining on the top sieve of Penn State Forage Particle Separator than postensiled corn silage. However, the difference between pre- and postensiled whole plant corn was less in experiment 2 than in experiment 1 . The reason for the increase in particle size of corn silage between pre- and postensiled corn silage harvested at the medium and long chops is unknown. However, compaction of the forage into the silo may have altered the physical characteristics of the forage (flattened some of the particles), making it difficult for some of the particles to pass through the screens in the particle separator. This may account for some of the increase in particle size. Also, the longer particle size increases the opportunity for sorting to occur because the forage size is less uniform. The whole plant corn in the truck may have been sorted during transport from the field to the silo and during silo filling for the 
longer whole plant corn (27.8 and $39.7 \mathrm{~mm}$ ). However, the whole plant corn harvested at a shorter chop length $(11.1 \mathrm{~mm})$ had less opportunity for sorting during transport and silo filling because the forage particles were more uniform in size.

Chop length of whole plant corn had a large impact on ALC estimated with Penn State Forage Particle Separator (Table 7). The ALC increased as the TLC increased for whole plant corn in experiments 1 and 2 (Table 7). In experiment 1 , as the TLC of whole plant corn increased from 11.1 to 27.8 to $39.7 \mathrm{~mm}$; the ALC of preensiled whole plant corn increased from 13.6 to 18.4 to $29.9 \mathrm{~mm}$, respectively, and the ALC of postensiled corn silage increased from 13.5 to 28.6 to $43.2 \mathrm{~mm}$, respectively (Table 7). In experiment 2 , as the TLC of whole plant corn increased from 27.8 to $39.7 \mathrm{~mm}$, the ALC of preensiled whole plant corn increased from 14.8 to $17.2 \mathrm{~mm}$, and the ALC of postensiled corn silage increased from 18.3 to $21.2 \mathrm{~mm}$, respectively.

Chop length of whole plant corn had a large impact on particle distribution estimated with Penn State Forage Particle Separator (Table 7). As TLC increased from 11.1 (short) to $27.8 \mathrm{~mm}$ (medium), the amount of particles remaining on the top sieve of Penn State Forage Particle Separator also increased for whole plant corn, in experiment $1(P<0.0001)$. The amount of postensiled corn silage particles remaining on the middle sieve (between 8 and $19 \mathrm{~mm}$ ) was lowest for corn silage harvested at a long chop length, followed by the medium and short chop lengths $(P<0.0001)$ in experiment 1 , and was lower $(P<0.0002)$ for corn silage harvested at a long chop length compared with a medium chop length in experiment 2 . The amount of post ensiled particles in the bottom pan $(<8 \mathrm{~mm})$ was greater for corn silage harvested at the long chop length compared to corn silage harvested at shorter chop lengths in experiments $1(P<0.009)$ and $2(P<0.09)$. These results indicate that increasing TLC at harvest changes the particle size distribution. There tends to be a lower percentage of particles on the middle screen (between 8 and 19 $\mathrm{mm}$ ) and a greater percentage of particles on the top $(>19 \mathrm{~mm})$ and bottom $(<8 \mathrm{~mm})$ layers of the Penn State Forage Particle Separator as the TLC increases.

Processing corn silage altered ALC and particle distribution (Table 7). Unprocessed corn silage had a greater ALC than processed corn silage in the five comparisons of unprocessed and processed corn silage in this study. In experiment 2 , the postensiled unprocessed corn silage had a greater $(P<0.04)$ percentage of particles on the top sieve $(>19 \mathrm{~mm})$ than the processed corn silage. Also, in experiments 1 and 2, postensiled processed corn silage had a greater $(P<0.09$ and $P<$ 0.004 , respectively) percentage of particles in the bottom pan $(<8 \mathrm{~mm})$ than unprocessed corn silage. These results suggest a reduction in particle size of corn silage due to mechanical processing.

Total mixed rations and orts. Particle distribution and ALC of the TMR was estimated with Penn State Forage Particle Separator (Table 8). The ALC of TMR containing the different corn silage treatments were reduced in experiments 1 and 2 compared to the ALC of corn silage (Table 8). The reduction in ALC was partially related to other feed ingredients being present in the TMR and the mixing in the Calan data rangers before feeding.

The particle distribution of the TMR was affected by chop length of the corn silage present in the TMR (Table 8). The percentage of TMR particles $>19 \mathrm{~mm}$ (top sieve) increased as the TLC of the corn silage present in the TMR increased in experiments $1(P<0.0001)$ and $2(P$ $<0.002)$. The opposite trend was observed for TMR particles between 8 and $19 \mathrm{~mm}$ (middle sieve). In experiment 1 , the percentage of particles between 8 and 19 mm was greater $(P<0.0001)$ for TMR containing corn silage harvested at a short chop length compared with TMR containing corn silage harvested at medium and long chop lengths. In experiment 2 , the percentage of particles between 8 and $19 \mathrm{~mm}$ (middle sieve) was greater $(P<0.0005)$ for TMR containing corn silage harvested at a medium chop length compared with TMR containing corn silage harvested at a long chop length.

The ALC and particle distribution of orts were measured with the Penn State Forage Particle Separator (Table 8). The orts had greater ALC and percentage of particles remaining on the top sieve $(>19 \mathrm{~mm})$ than TMR for each treatment in experiments 1 and 2 (Table 8). In experiment 1 , the ALC of orts was $\sim 44,111$, and $418 \%$ greater than the ALC of TMR containing corn silage harvested at the short, medium, and long chop lengths, respectively. In experiment 2, the ALC of orts was 148 and $317 \%$ greater than the ALC of the TMR containing corn silage harvested at a medium and long chop length, respectively. This was an indication that sorting occurred, and the diets that were actually consumed had a smaller particle size than the TMR that was offered. The amount of sorting increased as chop length increased.

Chop length of corn silage affected ALC and particle distribution of orts measured with Penn State Forage Particle Separator (Table 8). The ALC of orts increased as the chop length of the corn silage present in the orts increased. In experiment 1 , the orts containing the long chop corn silage had the greatest percentage of particles $>19 \mathrm{~mm}$ (top sieve) followed by the orts containing medium and short $(P<0.0001)$ chop lengths. Therefore, in experiment 1 , the orts containing short chop corn silage had a greater percentage of particles between 8 and $19 \mathrm{~mm}$ (middle sieve; $P<0.0001$ ) and $<8 \mathrm{~mm}$ (bot- 
Table 8. Penn State Forage Particle Separator DM distribution data for TMR and orts in experiments 1 and 2.

\begin{tabular}{|c|c|c|c|c|c|c|c|c|}
\hline Experiment & $\begin{array}{l}\text { TMR } \\
\text { ALC }^{1}\end{array}$ & $\begin{array}{l}\text { TMR } \\
\text { top } \\
\left(\mathrm{SS}^{2}=19 \mathrm{~mm}\right)\end{array}$ & $\begin{array}{l}\text { TMR } \\
\text { middle } \\
(\mathrm{SS}=8 \mathrm{~mm})\end{array}$ & $\begin{array}{l}\text { TMR } \\
\text { bottom }\end{array}$ & $\begin{array}{l}\text { Ort } \\
\text { ALC }\end{array}$ & $\begin{array}{l}\text { Ort } \\
\text { top } \\
(\mathrm{SS}=19 \mathrm{~mm})\end{array}$ & $\begin{array}{l}\text { Ort } \\
\text { middle } \\
(\mathrm{SS}=8 \mathrm{~mm})\end{array}$ & $\begin{array}{l}\text { Ort } \\
\text { bottom }\end{array}$ \\
\hline Experiment 1 & $\mathrm{~mm}$ & \multicolumn{3}{|c|}{$\longrightarrow$ (\% remaining on sieve $)$} & $\mathrm{mm}$ & \multicolumn{2}{|c|}{ (\% remaining on sieve $)$} & \\
\hline Short, unproc ${ }^{5}$ & 10.7 & $19.3^{\mathrm{c}}$ & 44.1 & 36.5 & 16.5 & 36.0 & 38.3 & 25.6 \\
\hline Medium $^{6}$, proc & 13.0 & $39.3^{\mathrm{b}}$ & 23.1 & 37.6 & 27.9 & 62.8 & 18.4 & 18.7 \\
\hline Medium, unproc & 17.3 & $46.6^{\mathrm{a}}$ & 21.2 & 32.2 & 30.5 & 65.9 & 17.5 & 16.6 \\
\hline $\mathrm{SE}$ & $\ldots$ & 3.06 & 1.92 & 1.89 & $\ldots$ & 6.07 & 3.56 & 3.16 \\
\hline Chop length effect & $\ldots$ & 0.0001 & 0.0001 & $\mathrm{NS}^{8}$ & $\ldots$ & 0.0001 & 0.0001 & 0.002 \\
\hline Processing effect & $\ldots$ & NS & NS & NS & $\ldots$ & NS & NS & NS \\
\hline Chop by proc effect & $\ldots$ & 0.17 & NS & NS & $\ldots$ & NS & NS & NS \\
\hline \multicolumn{9}{|l|}{ Experiment 2} \\
\hline Medium, proc & 8.9 & 23.9 & 32.4 & 43.7 & 17.3 & 46.5 & 23.2 & 30.3 \\
\hline Medium, unproc & 10.2 & 26.0 & 32.6 & 41.4 & 20.1 & 50.5 & 23.2 & 26.3 \\
\hline Chop by proc effect & $\cdots$ & NS & NS & NS & $\cdots$ & NS & NS & NS \\
\hline
\end{tabular}

${ }^{1} \mathrm{ALC}=$ Average length-of-cut. Determination made using Weibull paper provided in NASCO's ${ }^{\circledR}$ Penn State forage particle separator direction packet. Average particle length (X-axis) estimated by interpolation from the 50\% mark on the Y-axis (cumulative \% undersized).

${ }^{2} \mathrm{SS}=$ Screen size.

${ }^{3}$ Short - Corn silage was harvested at a TLC of $11.1 \mathrm{~mm}$.

${ }^{4}$ Proc - Corn silage was harvested with a 5830 John Deere harvester with kernel processing rolls set $1 \mathrm{~mm}$ apart.

${ }^{5}$ Unproc - Corn silage was harvested with a 5830 John Deere harvester with kernel processing rolls set $15.9 \mathrm{~mm}$ apart.

${ }^{6}$ Medium - Corn silage was harvested at a TLC of $27.8 \mathrm{~mm}$.

${ }^{7}$ Long - Corn silage was harvested at a TLC of $39.7 \mathrm{~mm}$.

${ }^{8} \mathrm{NS}-P>0.10$.

tom pan; $P<0.002$ ) than the orts containing the medium and long chop corn silages (Table 8). Similar trends were observed with the orts containing medium and long chop corn silages in experiment 2 . The orts containing long chop corn silage had a greater percentage of particles $>19 \mathrm{~mm}$ (top sieve; $P<0.01$ ), and a lower percentage of particles between 8 and $19 \mathrm{~mm}$ (middle sieve; $P<0.0002$ ), and $<8 \mathrm{~mm}$ (bottom pan; $P<0.10$ ) than the orts containing medium chop corn silage (Table 8).

\section{Intake, Digestibility, and N Balance}

DM and OM intake and digestibility. The $\mathrm{DM}$ and OM intake and digestibility data are presented in Table 9. Chop length of corn silage present in the diet affected intake, ruminal digestibility, and total tract digestibility of DM and OM (Table 9). In experiment 2, cows fed medium chop corn silage diets had a significantly greater intake of DM $(P<0.01)$ and OM $(P<0.01)$. However, there was a trend for a chop length by processing interaction of DM $(P=0.11)$ and $\mathrm{OM}(P<0.07)$ intake. Cows fed the medium chop unprocessed corn silage diets tended to have the greatest intake, and cows fed the other treatments had similar intakes. Therefore, the significant effect of chop length on DM and OM intake was mainly due to the greater intake by cows fed medium chop unprocessed corn silage-based diets.

Chop length of corn silage had an effect on ruminal and total tract digestibility of DM and $\mathrm{OM}$ in experiment 1. Apparent ruminal digestibility of DM $(P<0.07)$ and apparent total tract digestibility of DM $(P<0.08)$ and OM $(P<0.09)$ were lower for cows fed diets containing corn silage harvested at the short chop length compared with the medium and long chop lengths (Table 9). However, there was no difference in total tract $\mathrm{DM}$ and $\mathrm{OM}$ digestibilities between medium and long chop corn silage in experiments 1 and 2. Others have reported no difference in total tract $\mathrm{DM}$ and/or $\mathrm{OM}$ digestibilities when corn silage was harvested at different chop lengths (Weigand et al., 1993; Stockdale and Beavis, 1994; Bal et al., 2000).

Mechanical processing of corn silage also affected total tract digestibility of $\mathrm{DM}$ and $\mathrm{OM}$ in experiment 1 . Total tract digestibility of DM $(P<0.11)$ and $\mathrm{OM}(P<$ 0.08 ) tended to be greater for cows fed processed corn silage-based diets compared to unprocessed corn silagebased diets (Table 9). However, in experiment 2, total 
Table 9. Intake and digestion of DM and OM for cows in experiments 1 and 2 .

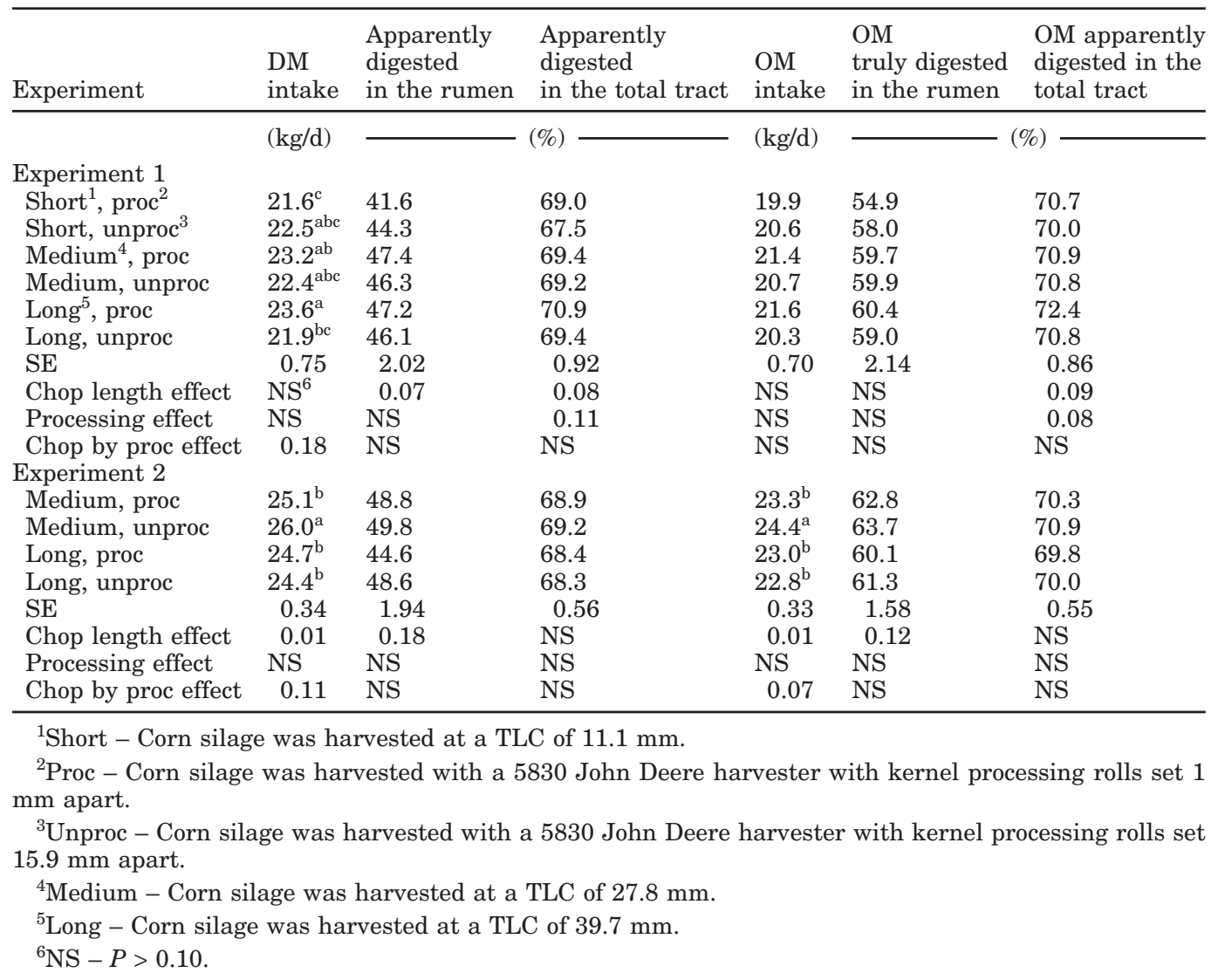

tract $\mathrm{DM}$ and $\mathrm{OM}$ digestibilities were similar between processed and unprocessed corn silage-based diets (Table 7). Others have reported similar total tract digestibility of DM and/or OM for cows fed diets containing processed and unprocessed corn silage (Rojas-Bourrillon et al., 1987; Bal et al., 2000; Dhiman et al., 2000).

Starch intake and digestibility. Starch intake and digestibility data are presented in Table 10. Chop length of corn silage had an effect on starch intake and digestibility in experiment 2 (Table 10). Starch intake was significantly greater $(P<0.004)$ for cows fed corn silage harvested at the medium chop length compared to the long chop length (experiment 2). However, there was a chop length by processing interaction $(P<0.04)$, and cows fed unprocessed corn silage harvested at the medium chop length had greater starch intake than cow fed the other corn silage treatments. Apparent ruminal $(P<0.03)$ and total tract $(P<0.009)$ starch digestibilities were greater for cows fed diets containing corn silage harvested at the medium chop length compared with the long chop length in experiment 2 . Starch intake and digestibility were not affected by corn silage chop length in experiment 1 . Others have reported no change in total tract starch digestibility due to chop length of corn silage (Weigand et al., 1993; Bal et al., 2000).

Processing corn silage affected starch digestibility. Cows fed diets containing processed corn silage had improved apparent postruminal $(P<0.09)$ and total tract $(P<0.001)$ starch digestibilities compared with cows fed unprocessed corn silage-based diets in experiment 2. Others have reported a significant increase in total tract starch digestibility when corn silage was mechanically processed (Rojas-Bourrillon et al., 1987; Young et al., 1998; Bal et al., 2000; Dhiman et al., 2000; Weiss and Wyatt, 2000; Johnson et al., 2002b). However, in experiment 1 , starch intake and digestibility were not affected by processing. The reason for no response in experiment 1 is unknown. However, it appears that the particle distribution (Table 7) and percentage of intact corn kernels (Table 3) tended to be similar between processed and unprocessed corn silage treatments. The only difference in the percentage of intact corn kernels was at the short chop length between processed and unprocessed corn silage. The intact corn kernels tended to be numerically greater for the processed corn silage, and ruminal and total tract starch digestibilities were numerically lower for the 
Table 10. Intake and digestion of starch (DM basis) in experiments 1 and 2 .

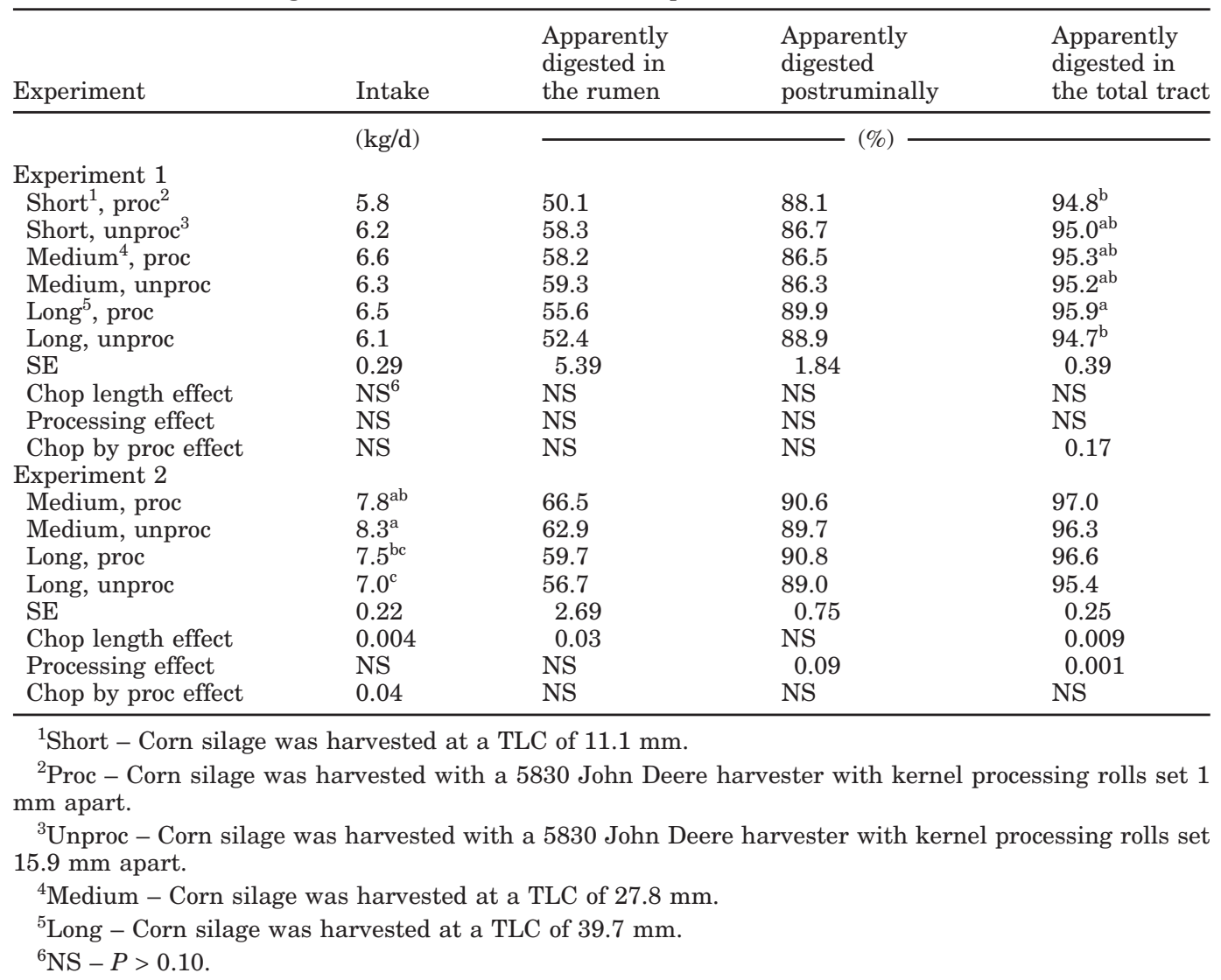

processed corn silage treatment at the short chop length.

NDF intake and digestibility. NDF intake and digestibility data are presented in Table 11. Intake of NDF was not affected by chop length in experiments 1 and 2 (Table 11). Total tract digestibility of NDF tended to increase as chop length increased from short to medium to long in experiment $1(P<0.07)$, and from medium to long in experiment $2(P=0.11)$. The greater total tract starch digestibility and lower total tract NDF digestibility for cows fed diets containing medium chop corn silage may have eliminated differences in total tract DM and OM digestibilities between diets (experiment 2; Tables 9 through 11).

Cows fed diets containing processed corn silage had a trend for lower apparent total tract digestibility of NDF $(P<0.10)$ than cows fed unprocessed corn silagebased diets in experiment 2 (Table 11). Others have reported no difference (Rojas-Bourrillon et al., 1987; Young et al., 1998; Bal et al., 2000; Weiss and Wyatt, 2000) or a decline (Dhiman et al., 2000) in total tract NDF digestibility when corn silage was processed. Forage NDF intake $(\mathrm{kg} / \mathrm{d}-P<0.02$ and $\%$ of $\mathrm{BW}-P<0.008)$ was greater for cows fed diets containing unprocessed medium chop corn silage compared with the other treatments in experiment 2 (Table 11). The greater forage NDF intake was mainly due to greater DMI for cows consuming unprocessed medium chop corn silage-based diets because forage NDF concentration in the diet (Table 6) and BW (Table 12) were similar between treatments.

Ether extract digestibility. Ether extract intake and digestibility data are presented in Table 13. There was a trend for increased intake $(P<0.08)$ and total tract digestibility $(P<0.07)$ of ether extract when cows were fed diets containing processed corn silage in experiment 1 (Table 13). Others have reported an increase in total tract digestibility of ether extract when cows were fed diets containing corn silage that was processed (Johnson et al., 2002b). However, there was no effect of processing on intake or total tract digestibility of ether extract in experiment 2.

Nitrogen intake, digestibility, and balance. Nitrogen intake, digestibility, and balance data are presented in Table 14 . N intake was greater $(P<0.06)$ for cows consuming diets containing corn silage harvested at the medium chop length in experiment 2. However, there was a chop length by processing interaction, and 
Table 11. Intake and digestion of NDF (DM basis) for experiments 1 and 2.

\begin{tabular}{|c|c|c|c|c|c|c|c|}
\hline Experiment & Intake & Intake & $\begin{array}{l}\text { Apparently } \\
\text { digested } \\
\text { in the rumen }\end{array}$ & $\begin{array}{l}\text { Apparently } \\
\text { digested } \\
\text { postruminally }\end{array}$ & $\begin{array}{l}\text { Apparently } \\
\text { digested in } \\
\text { the total tract }\end{array}$ & $\begin{array}{l}\text { Forage } \\
\text { intake }\end{array}$ & $\begin{array}{l}\text { Forage } \\
\text { intake }\end{array}$ \\
\hline & (kg/d) & $(\%$ of $\mathrm{BW})$ & $\longrightarrow$ & $-(\%)$ & - & $(\mathrm{kg} / \mathrm{d})$ & $(\%$ of $\mathrm{BW})$ \\
\hline \multicolumn{8}{|l|}{ Experiment 1} \\
\hline Short $^{1}$, proc $^{2}$ & 7.8 & 1.12 & 47.5 & 6.3 & 51.9 & 4.2 & 0.61 \\
\hline Short, unproc ${ }^{3}$ & 7.9 & 1.16 & 49.9 & -3.9 & 48.5 & 4.4 & 0.64 \\
\hline Medium ${ }^{4}$, proc & 8.2 & 1.20 & 56.4 & -13.6 & 52.4 & 4.3 & 0.64 \\
\hline Medium, unproc & 7.9 & 1.16 & 54.4 & -6.0 & 53.6 & 4.4 & 0.64 \\
\hline Long $^{5}$, proc & 8.2 & 1.21 & 54.9 & -2.5 & 53.9 & 4.4 & 0.65 \\
\hline Long, unproc & 7.8 & 1.15 & 55.4 & -4.5 & 53.6 & 4.3 & 0.63 \\
\hline $\mathrm{SE}$ & 0.30 & 0.043 & 2.70 & 5.40 & 1.69 & 0.14 & 0.021 \\
\hline Chop length effect & $\mathrm{NS}^{6}$ & NS & 0.02 & 0.11 & 0.07 & NS & NS \\
\hline Processing effect & NS & NS & NS & NS & NS & NS & NS \\
\hline Chop by proc effect & NS & NS & NS & NS & NS & NS & NS \\
\hline \multicolumn{8}{|l|}{ Experiment 2} \\
\hline Medium, proc & 8.3 & 1.27 & 48.9 & -12.6 & 44.0 & $4.7^{\mathrm{b}}$ & $0.71^{\mathrm{c}}$ \\
\hline Medium, unproc & 8.5 & 1.30 & 49.6 & -9.0 & 45.7 & $4.9^{\mathrm{a}}$ & $0.75^{\mathrm{a}}$ \\
\hline Long, proc & 8.5 & 1.30 & 46.3 & -9.2 & 45.6 & $4.8^{\mathrm{ab}}$ & $0.73^{\mathrm{ab}}$ \\
\hline Long, unproc & 8.5 & 1.30 & 52.9 & -15.5 & 47.6 & $4.8^{\mathrm{b}}$ & $0.73^{\mathrm{b}}$ \\
\hline $\mathrm{SE}$ & 0.16 & 0.023 & 2.56 & 5.06 & 1.08 & 0.06 & 0.009 \\
\hline Chop length effect & NS & NS & NS & NS & 0.11 & NS & NS \\
\hline Processing effect & NS & NS & 0.18 & NS & 0.10 & 0.07 & 0.03 \\
\hline Chop by proc effect & NS & NS & NS & NS & NS & 0.02 & 0.008 \\
\hline
\end{tabular}

${ }^{1}$ Short - Corn silage was harvested at a TLC of $11.1 \mathrm{~mm}$.

${ }^{2}$ Proc - Corn silage was harvested with a 5830 John Deere harvester with kernel processing rolls set $1 \mathrm{~mm}$ apart.

${ }^{3}$ Unproc - Corn silage was harvested with a $5830 \mathrm{John}$ Deere harvester with kernel processing rolls set $15.9 \mathrm{~mm}$ apart.

${ }^{4}$ Medium - Corn silage was harvested at a TLC of $27.8 \mathrm{~mm}$.

${ }^{5}$ Long - Corn silage was harvested at a TLC of $39.7 \mathrm{~mm}$.

${ }^{6} \mathrm{NS}-P>0.10$.

Table 12. Body weight, milk production, and milk composition of cows in experiments 1 and 2 .

\begin{tabular}{|c|c|c|c|c|c|c|c|c|c|c|}
\hline Experiment & $\begin{array}{l}\text { Body } \\
\text { weight }\end{array}$ & Milk & FCM & Fat & Fat & Protein & Protein & Total N & Casein $\mathrm{N}$ & MUN \\
\hline & $\longrightarrow$ & $(\mathrm{kg} / \mathrm{d})$ & 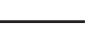 & $(\%)$ & $(\mathrm{kg} / \mathrm{d})$ & $(\%)$ & $(\mathrm{kg} / \mathrm{d})$ & 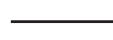 & & (mg/dL) \\
\hline $\begin{array}{l}\text { Short }{ }^{1}, \text { proc }^{2} \\
\text { Short, unproc }\end{array}$ & $\begin{array}{l}683 \\
680\end{array}$ & $\begin{array}{l}27.8 \\
28.2\end{array}$ & $\begin{array}{l}27.3 \\
27.6\end{array}$ & $\begin{array}{l}3.54^{\mathrm{a}} \\
3.43^{\mathrm{b}}\end{array}$ & $\begin{array}{l}0.94 \\
0.95\end{array}$ & $\begin{array}{l}3.14 \\
3.17\end{array}$ & $\begin{array}{l}0.85 \\
0.88\end{array}$ & $\begin{array}{l}0.605 \\
0.558\end{array}$ & $\begin{array}{l}0.444 \\
0.406\end{array}$ & $\begin{array}{l}14.7 \\
14.7\end{array}$ \\
\hline Medium $^{4}$, proc & 686 & $\begin{array}{l}20.4 \\
25.8\end{array}$ & 25.5 & $3.53^{\mathrm{ab}}$ & 0.89 & $\begin{array}{l}0.11 \\
3.24\end{array}$ & 0.80 & 0.615 & 0.460 & $\begin{array}{l}14.1 \\
14.3\end{array}$ \\
\hline Medium, unproc & 686 & 27.1 & 26.0 & $3.47^{\mathrm{ab}}$ & 0.88 & 3.16 & 0.84 & 0.587 & 0.374 & 14.9 \\
\hline SE & 7.3 & 1.57 & 1.88 & 0.147 & 0.078 & 0.051 & 0.052 & 0.0255 & 0.0364 & 1.142 \\
\hline Chop length effect & $\mathrm{NS}^{6}$ & NS & NS & NS & NS & NS & NS & NS & NS & NS \\
\hline Processing effect & NS & NS & NS & NS & NS & NS & NS & 0.13 & 0.12 & NS \\
\hline Chop by proc effect & NS & NS & NS & 0.10 & NS & NS & NS & NS & NS & NS \\
\hline \multicolumn{11}{|l|}{ Experiment 2} \\
\hline Medium, proc & 660 & 38.7 & $36.7^{\mathrm{ab}}$ & $3.21^{\mathrm{ab}}$ & $1.23^{\mathrm{b}}$ & 2.98 & 1.14 & 0.511 & 0.366 & 11.9 \\
\hline Medium, unproc & 659 & 38.1 & $35.6^{\mathrm{b}}$ & $3.07^{\mathrm{b}}$ & $1.18^{\mathrm{b}}$ & 3.01 & 1.14 & 0.524 & 0.390 & 12.6 \\
\hline Chop by proc effect & NS & NS & 0.14 & 0.14 & 0.08 & NS & NS & NS & NS & NS \\
\hline
\end{tabular}

${ }^{1}$ Short - Corn silage was harvested at a TLC of $11.1 \mathrm{~mm}$.

${ }^{2}$ Proc - Corn silage was harvested with a 5830 John Deere harvester with kernel processing rolls set $1 \mathrm{~mm}$ apart.

${ }^{3}$ Unproc - Corn silage was harvested with a 5830 John Deere harvester with kernel processing rolls set $15.9 \mathrm{~mm}$ apart.

${ }^{4}$ Medium - Corn silage was harvested at a TLC of $27.8 \mathrm{~mm}$.

${ }^{5}$ Long - Corn silage was harvested at a TLC of $39.7 \mathrm{~mm}$.

${ }^{6} \mathrm{NS}-P>0.10$. 
Table 13. Intake and digestion of ether extract (DM basis) in experiments 1 and 2 .

\begin{tabular}{lll}
\hline & Intake & $\begin{array}{c}\text { Apparently } \\
\text { digested in } \\
\text { the total tract }\end{array}$ \\
\hline Experiment & $(\mathrm{kg} / \mathrm{d})$ & $(\%)$ \\
Experiment 1 & & \\
Short $^{1}$, proc $^{2}$ & 1.04 & 89.9 \\
Short, unproc $^{3}$ & 1.06 & 88.7 \\
Medium $^{4}$, proc & 1.14 & 89.7 \\
Medium, unproc & 1.07 & 89.3 \\
Long, proc & 1.15 & 89.7 \\
Long, unproc & 1.06 & 88.3 \\
SE & 0.036 & 0.73 \\
Chop length effect & 0.16 & $\mathrm{NS}$ \\
Processing effect & 0.08 & 0.07 \\
Chop by proc effect & $\mathrm{NS}$ & $\mathrm{NS}$ \\
Experiment 2 & & \\
Medium, proc & $1.24^{\mathrm{b}}$ & $87.6^{\mathrm{ab}}$ \\
Medium, unproc & $1.32^{\mathrm{a}}$ & $88.5^{\mathrm{a}}$ \\
Long, proc & $1.28^{\mathrm{ab}}$ & $88.6^{\mathrm{a}}$ \\
Long, unproc & $1.26^{\mathrm{b}}$ & $86.8^{\mathrm{b}}$ \\
SE & 0.020 & 0.69 \\
Chop length effect & $\mathrm{NS}$ & $\mathrm{NS}$ \\
Processing effect & 0.14 & $\mathrm{NS}$ \\
Chop by proc effect & 0.03 & 0.07 \\
\hline
\end{tabular}

\footnotetext{
${ }^{1}$ Short - Corn silage was harvested at a TLC of $11.1 \mathrm{~mm}$.

${ }^{2}$ Proc-Corn silage was harvested with a 5830 John Deere harvester with kernel processing rolls set $1 \mathrm{~mm}$ apart.

${ }^{3}$ Unproc - Corn silage was harvested with a 5830 John Deere harvester with kernel processing rolls set $15.9 \mathrm{~mm}$ apart.

${ }^{4}$ Medium - Corn silage was harvested at a TLC of $27.8 \mathrm{~mm}$.

${ }^{5}$ Long - Corn silage was harvested at a TLC of $39.7 \mathrm{~mm}$.

${ }^{6} \mathrm{NS}-P>0.10$.
}

cows consuming the unprocessed medium chop length corn silage diet had significantly greater $(P<0.02) \mathrm{N}$ intake than the other treatments (experiment 2). The greater $\mathrm{N}$ intake is mainly related to the greater DMI (Table 9) for cows fed unprocessed medium chop length corn silage in experiment 2 , because the $\mathrm{CP}$ concentration (Table 6 ) of the diet consumed by the cows tended to be similar among treatments.

Ruminal digestion of $\mathrm{N}$ was not affected by chop length or processing in both experiments. However, there was a trend for greater postruminal $\mathrm{N}$ digestion for cows fed processed corn silage-based diets in experiments $1(P<0.07)$ and $2(P<0.09)$. There was also a trend for increased $(P<0.12)$ total tract digestibility of $\mathrm{N}$ for cows consuming diets containing processed corn silage in experiment 1 .

The $\mathrm{N}$ balance of cows fed diets differing in corn silage treatments is presented in Table 14. The amount of $\mathrm{N}$ excreted in the feces and secreted in milk did not differ statistically between treatments in experiments 1 and 2 (Table 14). In experiment 1 , cows fed diets containing corn silage harvested at a short chop length had a greater $(P<0.04)$ amount of $\mathrm{N}$ excreted in the urine compared with cows fed diets containing corn silage harvested at the medium and long chop lengths (Table 14).

Cows in both experiments were in a positive $\mathrm{N}$ balance (Table 14). This differs from other published data that suggested cows were in a negative $\mathrm{N}$ balance when fed a similar ration (Johnson et al., 2002c). The only difference in dietary composition between studies was the corn silage treatments (Johnson et al., 2002a).

\section{Nitrogen Metabolism}

In experiment 1 , chop length or processing method of corn silage did not significantly affect flow of $\mathrm{N}$ fractions to the duodenum [NAN, NANMN, microbial N (grams per day or percentage of duodenal N), and ammonia N; Table 15]. There was a trend $(P=0.11$ and $P=0.13$ ) for increased microbial $\mathrm{N}$ efficiency (microbial $\mathrm{N}$ synthesized per kilogram of OM apparently and truly digested) when cows were fed processed corn silage compared to unprocessed corn silage in experiment 2 (Table 15). The trend for increased microbial $\mathrm{N}$ efficiency when corn silage was processed was due to the trend $(P=$ 0.12 and $P=0.14$ ) for greater microbial $\mathrm{N}$ efficiency for cows fed processed long chop corn silage compared to unprocessed long chop corn silage (Table 15). The slight improvement in microbial $\mathrm{N}$ efficiency may be an indication that the protein and carbohydrate sources provided by the diet were available at an optimal time in the rumen in experiment 2 (Table 15).

\section{Ruminal Measurements}

Ruminal ammonia. The ammonia $\mathrm{N}$ concentration $(\mathrm{mg} / \mathrm{dl})$ in rumen fluid 2 and $6 \mathrm{~h}$ after feeding was measured in experiments 1 and 2 (Table 16). In experiment 1 , cows fed long chop unprocessed corn silagebased diets tended to have lower $(P<0.17)$ ruminal ammonia $\mathrm{N}$ concentrations $6 \mathrm{~h}$ after feeding compared to all other treatments (Table 16). The trend for the long chop unprocessed corn silage treatment to have lower ruminal ammonia $\mathrm{N}$ concentration lead to a significant chop length effect. In experiment 1, cows fed diets containing corn silage harvested at a long chop length $(P<0.06)$ had lower ruminal ammonia $\mathrm{N}$ concentrations $6 \mathrm{~h}$ after feeding than cows fed diets containing medium and short chop length corn silages (Table 16).

Ruminal pH. Rumen fluid $\mathrm{pH}$ was significantly affected by hour $(P<0.0001)$, hour $\times$ chop length $(P<$ $0.0005)$, and hour $\times$ processing $(P<0.07)$ interactions in experiment 1 . Ruminal $\mathrm{pH}$ was greater $(P<0.08)$ for cows fed corn silage-based diets harvested at a long chop length compared with a medium chop length at 1 $\mathrm{h}$ before feeding, and was significantly lower $(P<0.03)$ for cows fed corn silage-based diets harvested at a long 
Table 14. $\mathrm{N}$ intake, balance, and digestibility in experiments 1 and 2 .

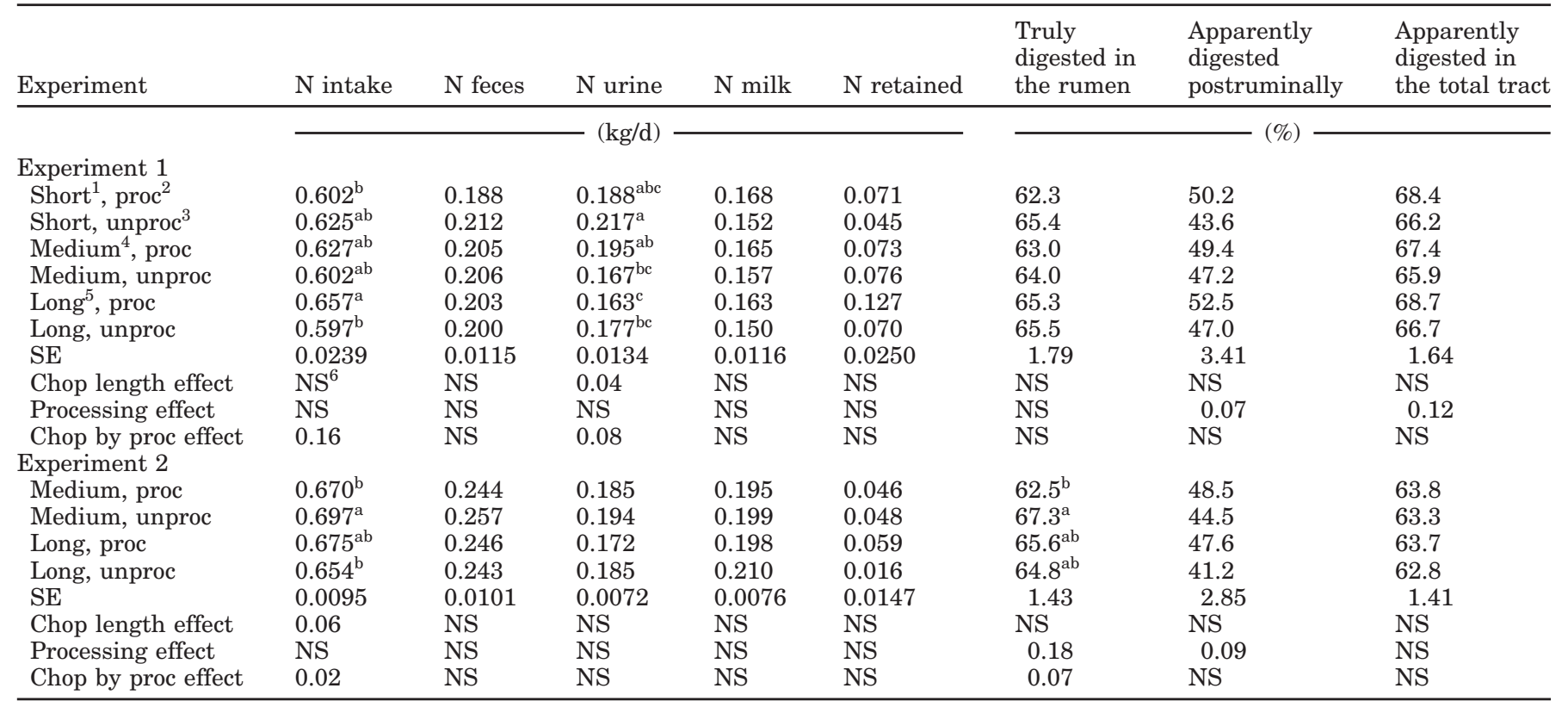

${ }^{1}$ Short - Corn silage was harvested at a TLC of $11.1 \mathrm{~mm}$.

${ }^{2}$ Proc - Corn silage was harvested with a 5830 John Deere harvester with kernel processing rolls set $1 \mathrm{~mm}$ apart.

${ }^{3}$ Unproc - Corn silage was harvested with a $5830 \mathrm{John}$ Deere harvester with kernel processing rolls set $15.9 \mathrm{~mm}$ apart.

${ }^{4}$ Medium - Corn silage was harvested at a TLC of $27.8 \mathrm{~mm}$.

${ }^{5}$ Long - Corn silage was harvested at a TLC of $39.7 \mathrm{~mm}$.

${ }^{6} \mathrm{NS}-P>0.10$.

chop length compared with a medium chop length at 5 and $6 \mathrm{~h}$ post feeding in experiment 1 (Figure 1a). In experiment 1 , cows fed processed corn silage-based diets had a significantly lower $(P<0.02) \mathrm{pH}$ than cows fed unprocessed corn silage-based diets $2 \mathrm{~h}$ postfeeding (Figure 1b). These results suggest that there is a delayed response in ruminal $\mathrm{pH}$ decline when a longer chop length corn silage is fed, and processing corn silage tends to cause a drop in ruminal $\mathrm{pH}$. In experiment 2 , ruminal $\mathrm{pH}$ was not significantly affected by hour $\times$ chop length, hour $\times$ processing, and hour $\times$ chop length $\times$ processing interactions.

Ruminal volatile fatty acids. Ruminal VFA and lactic acid concentrations were measured 2 and $6 \mathrm{~h}$ after feeding (Tables 16 and 17). Acetate concentrations ( $\mathrm{mol} / 100 \mathrm{~mol}$ ) were lower and propionate concentrations $(\mathrm{mol} / 100 \mathrm{~mol})$ were greater when diets containing hybrid Quanta were fed than when diets containing hybrid 3845 were fed (Table 16). The acetate-to-propionate ratio was also lower for hybrid Quanta than hybrid 3845 . These trends were similar to results observed in the literature, in which cows fed diets containing hybrid Quanta corn silage had a lower concentration of acetate and a greater concentration of propionate produced in the rumen than cows fed diets containing hybrid 3845 corn silage (Johnson et al., 2002c). The results in the current and published experiments indicate that the diets containing hybrid 3845 corn silage at approximately $27 \%$ of diet DM favor fiber-digesting bacteria, and diets containing hybrid Quanta corn silage at approximately $27 \%$ of diet DM favor starch-digesting bacteria in the rumen. The low acetate-to-propionate ratio in experiment 2 indicates that there was a large amount of rapidly fermentable carbohydrates in the rumen. $\mathrm{Al}-$ though the roughage-to-concentrate ratio of the diet DM was similar between experiments, the overall increase in starch concentration (Tables 5 and 6 ) in the diet in experiment 2 caused a shift in the types of VFA produced in the rumen.

There was no significant difference in the total amount of VFA ( $\mu \mathrm{mol} / \mathrm{ml})$ in the rumen 2 and $6 \mathrm{~h}$ after feeding for experiments 1 and 2 (Table 17). Therefore, the shift in the ratio of acetate to propionate between experiments was similar on a molar basis (mol/ 100 mol) and total production basis $(\mu \mathrm{mol} / \mathrm{ml})$. Van Soest (1994) reported that previously published data presented on a molar basis had shifts in the acetate-topropionate ratio between diets. However, total amount of VFA produced in the rumen was different between treatments, and when the acetate-to-propionate ratio was calculated from total VFA production data there 
Table 15. Flow of $\mathrm{N}$ fractions to the duodenum and microbial $\mathrm{N}$ efficiency in cows in experiments 1 and 2.

\begin{tabular}{|c|c|c|c|c|c|c|c|}
\hline Experiment & $\mathrm{NAN}^{1}$ & Microbial N & Microbial N & NANMN $^{2}$ & Ammonia $\mathrm{N}$ & $\begin{array}{l}\text { Microbial N } \\
\text { efficiency }\end{array}$ & $\begin{array}{l}\text { Microbial N } \\
\text { efficiency }\end{array}$ \\
\hline & 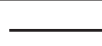 & $\mathrm{g} / \mathrm{d})$ & $(\%$ of duodenal $\mathrm{N})$ & 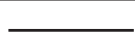 & d) & $\left(\mathrm{g} / \mathrm{kg} \mathrm{OMAD}^{3}\right)$ & $\left(\mathrm{g} / \mathrm{kg} \mathrm{OMTD}^{4}\right)$ \\
\hline \multicolumn{8}{|l|}{ Experiment 1} \\
\hline Short, unproc ${ }^{7}$ & 376.1 & 178.6 & 43.9 & 197.6 & 18.8 & 18.2 & 14.9 \\
\hline Medium $^{8}$, proc & 392.2 & 178.7 & 43.8 & 213.6 & 18.8 & 17.5 & 14.6 \\
\hline Medium, unproc & 390.0 & 193.0 & 47.2 & 197.0 & 20.2 & 19.9 & 16.2 \\
\hline $\mathrm{SE}$ & 21.76 & 21.72 & 3.43 & 11.68 & 1.49 & 2.72 & 1.81 \\
\hline Chop length effect & $\mathrm{NS}^{10}$ & NS & NS & NS & NS & NS & NS \\
\hline Processing effect & NS & NS & NS & NS & NS & NS & NS \\
\hline Chop by proc effect & NS & NS & NS & NS & NS & NS & NS \\
\hline \multicolumn{8}{|l|}{ Experiment 2} \\
\hline Medium, proc & 452.8 & $222.7^{\mathrm{ab}}$ & $47.2^{\mathrm{ab}}$ & 230.1 & $19.2^{\mathrm{a}}$ & $19.0^{\mathrm{ab}}$ & $15.7^{\mathrm{ab}}$ \\
\hline Medium, unproc & 446.5 & $239.6^{\mathrm{a}}$ & $50.8^{\mathrm{a}}$ & 206.9 & $19.6^{\mathrm{a}}$ & $18.9^{\mathrm{ab}}$ & $15.6^{\mathrm{ab}}$ \\
\hline Chop by proc effect & NS & 0.03 & 0.02 & NS & 0.13 & 0.12 & 0.14 \\
\hline
\end{tabular}

${ }^{1}$ NAN - Nitrogen from microbial and feed sources.

${ }^{2}$ NANMN - Nonammonia, nonmicrobial N; $\mathrm{N}$ from feed sources.

${ }^{3} \mathrm{OMAD}$ - Organic matter apparently digested.

${ }^{4}$ OMTD - Organic matter truly digested.

${ }^{5}$ Short - Corn silage was harvested at a TLC of $11.1 \mathrm{~mm}$.

${ }^{6}$ Proc - Corn silage was harvested with a 5830 John Deere harvester with kernel processing rolls set $1 \mathrm{~mm}$ apart.

${ }^{7}$ Unproc - Corn silage was harvested with a 5830 John Deere harvester with kernel processing rolls set $15.9 \mathrm{~mm}$ apart.

${ }^{8}$ Medium - Corn silage was harvested at a TLC of $27.8 \mathrm{~mm}$.

${ }^{9}$ Long - Corn silage was harvested at a TLC of $39.7 \mathrm{~mm}$.

${ }^{10} \mathrm{NS}-P>0.10$.

were different trends than when it was calculated as a molar proportion.

Mechanical processing of corn silage influenced the concentrations of acetate and propionate in the rumen in experiment 2 (Table 16). There was a significant decrease in the acetate concentration $(P<0.02)$ and the acetate-to-propionate ratio $(P<0.01)$ and a significant increase in propionate concentration $(P<0.02) 2 \mathrm{~h}$ after feeding for cows fed processed corn silage-based diets (experiment 2; Table 16). Others have reported a significant increase in propionate concentrations (RojasBourrillon et al., 1987; Doggett, 1998; Dhiman et al., 2000) and a significant decrease in the acetate-to-propionate ratio (Rojas-Bourrillon et al., 1987; Doggett, 1998) and acetate concentration (Doggett, 1998; Dhiman et al., 2000) when processed corn silage-based diets were fed.

Cows fed corn silage harvested at a long chop length had a trend for greater butyrate concentration $(P<$ $0.10)$ than cows fed corn silage harvested at a medium chop length (Table 16). Some have reported that butyrate concentrations tend to be greater in the rumen when less fermentable carbohydrate sources are avail- able in the rumen (Aldrich et al., 1993; Johnson et al., 2002c), while others have reported a decline in butyrate concentration when corn silage was harvested at a long chop length $(1.90 \mathrm{~cm})$ compared with a short chop length $(0.95 \mathrm{~cm}$; Stockdale and Beavis, 1994; Bal et al., 2000). In experiment 2 , ruminal starch digestibility was significantly lower $(P<0.03)$ for cows fed diets containing corn silage harvested at a long chop length compared to cows fed corn silage harvested at a medium chop length (Table 10). Therefore, there was less fermentable carbohydrate sources in the rumen for cows fed long chop corn silage in experiment 2 which may have led to an increase in butyrate concentration in the rumen (Tables 10 and 16).

\section{Energy Data}

Urinary energy, digestible energy, and metabolizable energy of the TMR. Chop length of corn silage affected the urinary energy output of cows in experiments 1 and 2 (Table 18). In experiment 1, urinary energy ( $\mathrm{Mcal} / \mathrm{d} ; P<0.08)$ tended to be greater for cows fed diets containing corn silage harvested at a short 
Table 16. Rumen fluid ammonia N, acetate, propionate, and butyrate concentrations, and A:P ratio 2 and $6 \mathrm{~h}$ after feeding in experiments 1 and 2.

\begin{tabular}{|c|c|c|c|c|c|c|c|c|c|c|}
\hline \multirow[b]{2}{*}{ Experiment } & \multicolumn{2}{|c|}{ Ammonia $\mathrm{N}$} & \multicolumn{2}{|c|}{ Acetate } & \multicolumn{2}{|c|}{ Propionate } & \multicolumn{2}{|c|}{ Butyrate } & \multicolumn{2}{|c|}{ A:P } \\
\hline & $2 \mathrm{~h}$ & $6 \mathrm{~h}$ & $2 \mathrm{~h}$ & $6 \mathrm{~h}$ & $2 \mathrm{~h}$ & $6 \mathrm{~h}$ & $2 \mathrm{~h}$ & $6 \mathrm{~h}$ & $2 \mathrm{~h}$ & $6 \mathrm{~h}$ \\
\hline & \multicolumn{2}{|c|}{$-(\mathrm{mg} / \mathrm{dL})-$} & & & & \multicolumn{2}{|c|}{$(\mathrm{mol} / 100 \mathrm{~mol})$} & & & \\
\hline \multicolumn{11}{|l|}{ Experiment 1} \\
\hline Short $^{1}$, proc $^{2}$ & $21.0^{\mathrm{b}}$ & $11.7^{\mathrm{a}}$ & 61.9 & $63.1^{\mathrm{a}}$ & 22.5 & 22.5 & 12.4 & 11.6 & 2.8 & 2.8 \\
\hline Short, unproc ${ }^{3}$ & $24.9^{\mathrm{a}}$ & $12.8^{\mathrm{a}}$ & 61.6 & $60.8^{\mathrm{b}}$ & 22.5 & 23.6 & 12.6 & 12.6 & 2.8 & 2.6 \\
\hline Medium $^{4}$, proc & $22.2^{\mathrm{ab}}$ & $12.4^{\mathrm{a}}$ & 61.1 & $60.9^{\mathrm{b}}$ & 22.9 & 23.8 & 12.7 & 12.3 & 2.7 & 2.6 \\
\hline Medium, unproc & $22.4^{\mathrm{ab}}$ & $11.3^{\mathrm{a}}$ & 62.2 & $61.9^{\mathrm{ab}}$ & 22.3 & 22.7 & 12.2 & 12.4 & 2.8 & 2.8 \\
\hline Long $^{5}$, proc & $25.1^{\mathrm{a}}$ & $11.4^{\mathrm{a}}$ & 61.5 & $61.2^{\mathrm{b}}$ & 22.9 & 23.3 & 12.4 & 12.5 & 2.7 & 2.7 \\
\hline Long, unproc & $22.9^{\mathrm{ab}}$ & $9.0^{\mathrm{b}}$ & 61.0 & $61.3^{\mathrm{b}}$ & 23.1 & 23.5 & 12.6 & 12.4 & 2.7 & 2.6 \\
\hline $\mathrm{SE}$ & 1.75 & 0.97 & 0.53 & 0.68 & 0.65 & 0.73 & 0.36 & 0.43 & 0.095 & 0.10 \\
\hline Chop length effect & $\mathrm{NS}^{6}$ & 0.06 & NS & NS & NS & NS & NS & NS & NS & NS \\
\hline Processing effect & NS & NS & NS & NS & NS & $\mathrm{NS}$ & NS & NS & NS & NS \\
\hline Chop by proc effect & 0.16 & 0.17 & NS & 0.05 & NS & NS & NS & NS & NS & 0.18 \\
\hline \multicolumn{11}{|l|}{ Experiment 2} \\
\hline Medium, proc & 19.3 & $6.5^{\mathrm{b}}$ & 57.5 & 57.4 & 26.8 & 28.9 & 12.3 & 11.1 & 2.2 & 2.0 \\
\hline Medium, unproc & 18.4 & $9.1^{\mathrm{a}}$ & 59.1 & 58.5 & 24.9 & 26.7 & 12.7 & 11.9 & 2.4 & 2.2 \\
\hline Long, proc & 17.6 & $8.8^{\mathrm{a}}$ & 57.6 & 55.6 & 26.6 & 29.1 & 12.6 & 12.4 & 2.2 & 1.9 \\
\hline Long, unproc & 17.4 & $7.2^{\mathrm{b}}$ & 58.5 & 57.0 & 26.0 & 27.7 & 12.3 & 12.6 & 2.3 & 2.1 \\
\hline $\mathrm{SE}$ & 1.27 & 0.609 & 0.47 & 1.33 & 0.51 & 1.30 & 0.41 & 0.64 & 0.06 & 0.14 \\
\hline effect & NS & NS & NS & 0.17 & NS & NS & NS & 0.10 & NS & NS \\
\hline ig effect & NS & NS & 0.02 & NS & 0.02 & 0.12 & NS & NS & 0.01 & 0.14 \\
\hline Chop by proc effect & NS & 0.003 & NS & NS & NS & NS & NS & NS & 0.19 & NS \\
\hline
\end{tabular}

${ }^{1}$ Short - Corn silage was harvested at a TLC of $11.1 \mathrm{~mm}$.

${ }^{2}$ Proc - Corn silage was harvested with a 5830 John Deere harvester with kernel processing rolls set 1 mm apart.

${ }^{3}$ Unproc - Corn silage was harvested with a 5830 John Deere harvester with kernel processing rolls set $15.9 \mathrm{~mm}$ apart.

${ }^{4}$ Medium - Corn silage was harvested at a TLC of $27.8 \mathrm{~mm}$.

${ }^{5}$ Long - Corn silage was harvested at a TLC of $39.7 \mathrm{~mm}$.

${ }^{6} \mathrm{NS}-P>0.10$.

(3.11 Mcal/d) chop length compared to diets containing corn silage harvested at medium $(2.76 \mathrm{Mcal} / \mathrm{d})$ and long (2.68 Mcal/d) chop lengths (Table 18). The greater urinary energy output for cows fed diets containing short chop length corn silage was partially due to the trend for a greater $(P=0.14)$ concentration of $\mathrm{N}$ in the urine compared to cows fed diets containing the long chop length corn silage. Urinary energy in this study is strongly correlated to the concentration of $\mathrm{N}$ in the urine because urinary $\mathrm{N}$ concentration was used to predict urinary energy output. In experiment 2 , cows fed diets containing corn silage harvested at a medium chop length tended to have greater urinary energy output (Mcal/d; $P<0.08$ ) compared with TMR containing corn silage harvested at a long chop length (Table 18). However, in experiment 2 , the greater urinary energy output was mainly due to increased output of urine $(P<$ 0.07 ) because urinary $\mathrm{N}$ concentrations were similar between treatments.

In experiment 1 , metabolizable energy (ME; \% of DE; $P<0.02$ ) was greater for cows fed diets containing corn silage harvested at a long chop length compared with cows fed diets containing corn silage harvested at a short chop length (Table 18). Metabolizable energy is affected by methane production in the rumen and $\mathrm{N}$ excretion in the urine. The fiber concentration of the TMR (Table 5) and methane production (Table 18) in the rumen tended to be similar at all chop lengths in experiment 1 . Therefore, it appears that reduced urinary $\mathrm{N}$ excretion $(P<0.04$; Table 14$)$ for cows fed long chop corn silage diets compared with short chop corn silage diets may have been what improved ME concentration (\% of DE).

In experiment 1 , the concentration and amount of $\mathrm{DE}$ and $\mathrm{ME}$ consumed by each treatment was similar. However, in experiment 2, the amount of $\mathrm{DE}(\mathrm{Mcal} / \mathrm{d}$; $P<0.04), \mathrm{ME}(\mathrm{Mcal} / \mathrm{d} ; P<0.06)$, and $\mathrm{NE}_{\mathrm{L}}(\mathrm{Mcal} / \mathrm{d} ; P<$ 0.02) consumed was greater for medium chop length corn silage diets compared long chop length corn silage diets (Table 18). The greater $\mathrm{DE}, \mathrm{ME}$, and $\mathrm{NE}_{\mathrm{L}}$ consumed in megacalories per day was due to greater DMI $(P<0.01$; Table 9) for cows fed TMR containing corn silage harvested at a medium chop length. It was not due to energy concentration in the TMR because the megacalories of energy ( $\mathrm{DE}, \mathrm{ME}$, and $\mathrm{NE}_{\mathrm{L}}$ ) per kilogram of TMR were similar between medium and long chop length corn silage treatments (Table 18). 

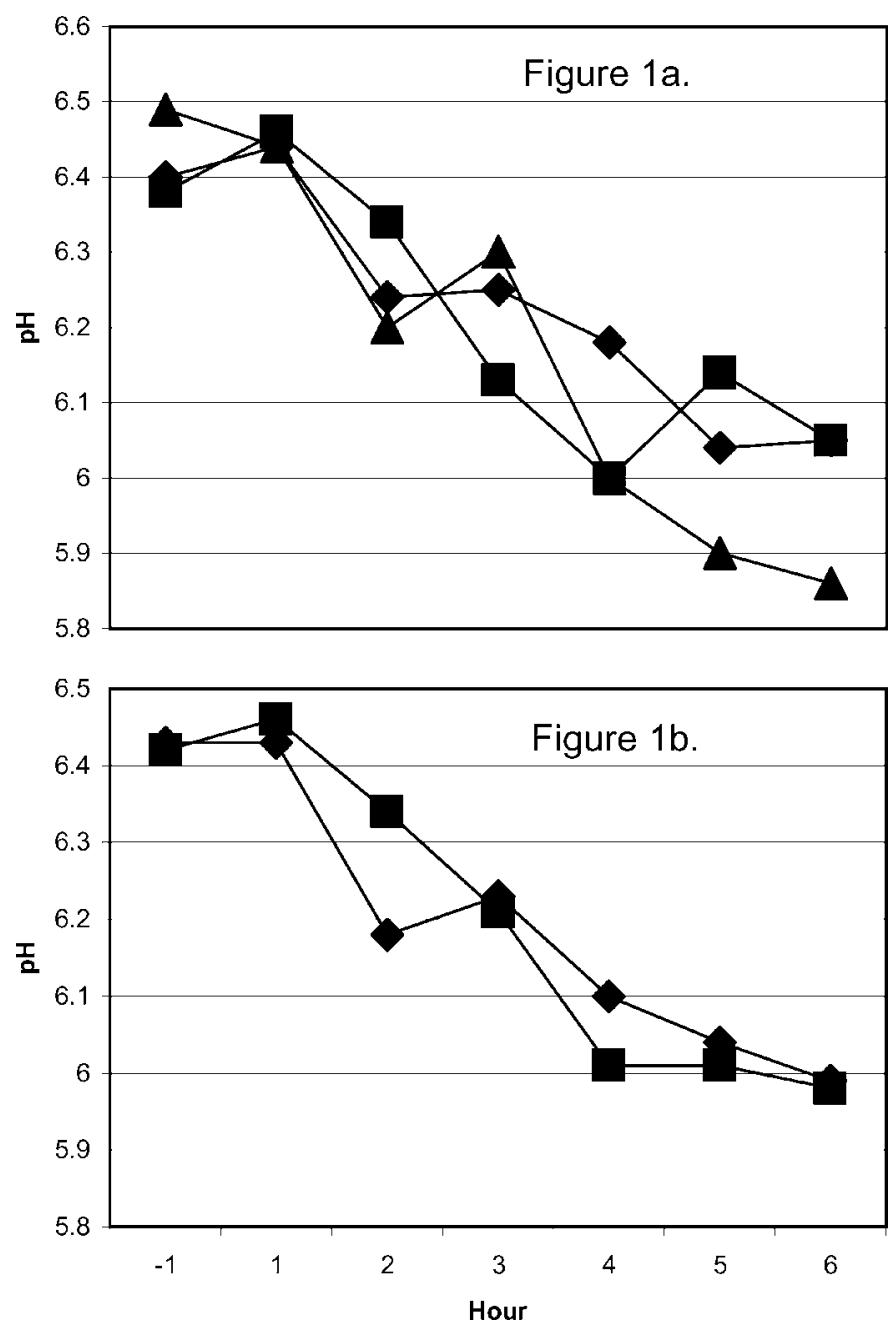

Figure 1. Ruminal $\mathrm{pH}$ relative to time of feeding for cows fed corn silage-based diets that differed in chop length [Figure 1a; experiment 1 - short chop ( ), medium chop ( $\mathbf{\square})$, and long chop ( $\mathbf{\Lambda})$ ], and processing method [Figure $1 \mathrm{~b}$; experiment 1 - processed ( $)$ and unpro-

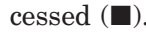

Total digestible nutrients and $N E_{L}$ concentration of TMR. The TDN was measured two ways in this study. TDN was estimated from digestible CP, digestible NFC, digestible NDF, and digestible fat, and is referred to as measured TDN in this paper (Table 18). TDN was also estimated from measured DE [TDN = $\mathrm{DE}(\mathrm{Mcal} / \mathrm{kg}) / 0.04409 ; \mathrm{NRC}, 1989]$ and is referred to as calculated TDN in this paper. TDN measured from nutrient digestibilities (70.0 and 70.1, respectively) was similar to TDN calculated from DE (measured with bomb calorimetry; 71.1 and $69.7 \%$, respectively) in experiments 1 and 2 .

In experiment 1, chop length and processing affected the measured TDN concentration of diets (Table 18). Measured TDN $(\% ; P<0.10)$ and $\mathrm{NE}_{\mathrm{L}}$ concentrations
(Mcal $/ \mathrm{kg} ; P<0.08$ ) of diets containing corn silage harvested at the short chop length tended to be lower than for diets containing corn silage harvested at the long chop length (Table 18; experiment 1). The lower TDN (\%) and $\mathrm{NE}_{\mathrm{L}}$ concentrations (Mcal/kg) of diets containing short chop length corn silage can be attributed to the trend for lower total tract DM $(P<0.08), \mathrm{OM}(P$ $<0.09)$, and NDF $(P<0.07)$ digestibilities compared to diets containing long chop corn silage (Tables 9 and 11). In both experiments, there was no difference in $\mathrm{TDN}(\%)$ or $\mathrm{NE}_{\mathrm{L}}$ concentrations $(\mathrm{Mcal} / \mathrm{kg}$ ) between diets containing medium and long chop corn silage. There is a lack of information in the literature on the effects of corn silage chop length on energy content of the ration. However, Bal et al. (2000) reported that fiber digestibility for cows fed diets containing processed corn silage harvested at short chop lengths $(0.95 \mathrm{~cm})$ was lower than at long chop lengths $(1.90 \mathrm{~cm})$, and starch digestibility was similar at all chop lengths. This suggests that energy digestibility had the potential to be greater at longer chop lengths.

Measured TDN $(\% ; P<0.09)$ and $\mathrm{NE}_{\mathrm{L}}$ concentrations $(\mathrm{Mcal} / \mathrm{kg} ; P<0.08)$ tended to be greater for diets containing processed corn silage compared with unprocessed corn silage (Table 18; experiment 1 ). The greater TDN $(\%)$ and $\mathrm{NE}_{\mathrm{L}}$ concentrations (Mcal/kg) of diets containing processed corn silage is attributed to greater OM $(P<0.08$; Table 9$)$ and ether extract $(P<0.07$; Table 13) digestibilities compared with diets containing unprocessed corn silage. The percentage of TDN and $\mathrm{NE}_{\mathrm{L}}$ concentrations $(\mathrm{Mcal} / \mathrm{kg}$ ) were, on average, 1.4 and $1.9 \%$ greater for cows fed diets containing processed corn silage compared to unprocessed corn silage in experiment 1 . Others have reported an increase TDN and $\mathrm{NE}_{\mathrm{L}}$ concentrations when diets containing processed corn silage were fed in place of unprocessed corn silage (Weiss and Wyatt, 2000, 5\% improvement; Johnson et al., 2002b, $\sim 2.4 \%$ improvement). In experiment 2 , there was no effect of processing corn silage on measured $\mathrm{TDN}(\%)$ and $\mathrm{NE}_{\mathrm{L}}$ concentrations (Mcal/kg; Table 18) of the diet. The lack of response in energy content is due to the opposing effects of increased total tract starch digestibility $(P<0.001$; Table 10$)$ and lower total tract NDF digestibility $(P<0.10$; Table 11$)$ for cows fed diets containing processed corn silage compared to unprocessed corn silage. Others have reported similar trends (Rojas-Bourrillon et al., 1987).

Energy requirements based on milk production and maintenance. Energy requirements (DE and $\mathrm{NE}_{\mathrm{L}}$ ) needed for milk production and maintenance based on actual milk production and body weight data collected in this study were reported in Table 19. Chop length and processing of corn silage had an effect on $\mathrm{DE}$ and $\mathrm{NE}_{\mathrm{L}}$ requirements of cows in this study (Table 
Table 17. Rumen fluid isobutyrate, isovalerate, valerate, lactate, and total VFA concentrations 2 and $6 \mathrm{~h}$ after feeding in cows in experiments 1 and 2.

\begin{tabular}{|c|c|c|c|c|c|c|c|c|c|c|}
\hline \multirow[b]{2}{*}{ Experiment } & \multicolumn{2}{|c|}{ Isobutyrate } & \multicolumn{2}{|c|}{ Isovalerate } & \multicolumn{2}{|c|}{ Valerate } & \multicolumn{2}{|c|}{ Sum VFA } & \multicolumn{2}{|c|}{ Lactate } \\
\hline & $2 \mathrm{~h}$ & $6 \mathrm{~h}$ & $2 \mathrm{~h}$ & $6 \mathrm{~h}$ & $2 \mathrm{~h}$ & $6 \mathrm{~h}$ & $2 \mathrm{~h}$ & $6 \mathrm{~h}$ & $2 \mathrm{~h}$ & $6 \mathrm{~h}$ \\
\hline & & & $(\mathrm{mol} / 10$ & $\mathrm{mol})$ & & & $-(\mu \mathrm{m}$ & $/ \mathrm{mL})-$ & $-(\mu \mathrm{mc}$ & $(\mathrm{mL})$ \\
\hline \multicolumn{11}{|l|}{ Experiment 1} \\
\hline Short $^{1}$, proc $^{2}$ & 0.98 & $0.86^{\mathrm{ab}}$ & 0.79 & 0.67 & 1.4 & $1.2^{\mathrm{b}}$ & 95.4 & 103.7 & 0.25 & 0.28 \\
\hline Short, unproc ${ }^{3}$ & 1.02 & $0.90^{\mathrm{a}}$ & 0.82 & 0.73 & 1.5 & $1.4^{\mathrm{a}}$ & 99.3 & 102.6 & 0.34 & 0.12 \\
\hline Medium $^{4}$, proc & 0.97 & $0.93^{\mathrm{a}}$ & 0.81 & 0.73 & 1.5 & $1.3^{\mathrm{ab}}$ & 100.6 & 102.3 & 0.34 & 0.08 \\
\hline Medium, unproc & 1.01 & $0.88^{\mathrm{a}}$ & 0.82 & 0.72 & 1.4 & $1.4^{\mathrm{a}}$ & 93.1 & 104.5 & 0.90 & 0.20 \\
\hline Long ${ }^{5}$, proc & 1.00 & $0.89^{\mathrm{a}}$ & 0.83 & 0.72 & 1.4 & $1.4^{\mathrm{a}}$ & 103.9 & 112.7 & 0.32 & 0.06 \\
\hline Long, unproc & 1.01 & $0.78^{\mathrm{b}}$ & 0.84 & 0.66 & 1.5 & $1.3^{\mathrm{ab}}$ & 96.8 & 102.8 & 0.17 & 0.11 \\
\hline SE & 0.030 & 0.035 & 0.028 & 0.032 & 0.05 & 0.04 & 4.72 & 5.78 & 0.23 & 0.083 \\
\hline Chop length effect & $\mathrm{NS}^{6}$ & 0.12 & NS & NS & NS & NS & NS & NS & 0.19 & NS \\
\hline Processing effect & 0.13 & 0.19 & NS & NS & NS & 0.16 & NS & NS & NS & NS \\
\hline Chop by proc effect & NS & 0.12 & NS & 0.19 & NS & 0.06 & NS & NS & NS & 0.19 \\
\hline \multicolumn{11}{|l|}{ Experiment 2} \\
\hline Medium, proc & 0.95 & $0.73^{b}$ & 0.80 & $0.60^{\mathrm{b}}$ & 1.6 & 1.3 & 106.3 & 121.1 & 0.06 & 0.11 \\
\hline Medium, unproc & 0.95 & $0.80^{\mathrm{a}}$ & 0.80 & $0.67^{\mathrm{a}}$ & 1.6 & 1.4 & 99.3 & 116.4 & 0.06 & 0.04 \\
\hline Long, proc & 0.85 & $0.76^{\mathrm{ab}}$ & 0.73 & $0.65^{\mathrm{ab}}$ & 1.6 & 1.4 & 106.3 & 128.1 & 0.16 & 0.19 \\
\hline Long, unproc & 0.89 & $0.73^{\mathrm{b}}$ & 0.77 & $0.60^{\mathrm{b}}$ & 1.6 & 1.4 & 97.9 & 119.9 & 0.05 & 0.31 \\
\hline $\mathrm{SE}$ & 0.031 & 0.028 & 0.023 & 0.031 & 0.05 & 0.07 & 6.18 & 7.32 & 0.039 & 0.133 \\
\hline Chop length effect & 0.03 & NS & 0.03 & NS & NS & NS & NS & NS & $\mathrm{NS}$ & 0.15 \\
\hline Processing effect & NS & NS & NS & NS & NS & NS & NS & NS & NS & NS \\
\hline Chop by proc effect & NS & 0.06 & NS & 0.04 & NS & NS & NS & NS & 0.16 & NS \\
\hline
\end{tabular}

${ }^{1}$ Short - Corn silage was harvested at a TLC of $11.1 \mathrm{~mm}$.

${ }^{2}$ Proc - Corn silage was harvested with a 5830 John Deere harvester with kernel processing rolls set 1 mm apart.

${ }^{3}$ Unproc - Corn silage was harvested with a 5830 John Deere harvester with kernel processing rolls set $15.9 \mathrm{~mm}$ apart.

${ }^{4}$ Medium - Corn silage was harvested at a TLC of $27.8 \mathrm{~mm}$.

${ }^{5}$ Long - Corn silage was harvested at a TLC of $39.7 \mathrm{~mm}$.

${ }^{6} \mathrm{NS}-P>0.10$.

19). Digestible energy required for milk production and maintenance tended to be greater $(P<0.09)$ for cows fed diets containing long chop corn silage than medium chop corn silage in experiment 2 . This was opposite of trends reported for the amount (Mcal/d) of $\mathrm{DE}$ and $\mathrm{NE}_{\mathrm{L}}$ present in the TMR (Table 18). The reason for the trend in energy requirements is unknown because milk production was not different between treatments, and BW was greater $(P<0.03)$ for cows fed diets containing medium chop length corn silage in experiment 2 (Table 12).

The amount of $\mathrm{DE}$ and $\mathrm{NE}_{\mathrm{L}}$ consumed was subtracted from the $\mathrm{DE}$ and $\mathrm{NE}_{\mathrm{L}}$ required for milk production and maintenance (Table 19). In both experiments, more energy ( $\mathrm{DE}$ and $\mathrm{NE}_{\mathrm{L}}$ ) was consumed than was needed for milk production and maintenance (Table 19). The amount of energy required ( $\mathrm{DE}$ and $\mathrm{NE}_{\mathrm{L}}$ ) for milk production and maintenance may have been underestimated because the experimental design did not allow for accurate adjustments in energy usage due to BW change. Therefore, energy required for changes in BW were not accounted for. There was a greater difference between $\mathrm{DE}$ intake and $\mathrm{DE}$ required $(P<0.07)$ and $\mathrm{NE}_{\mathrm{L}}$ intake and $\mathrm{NE}_{\mathrm{L}}$ required $(P<0.01)$ for cows consuming diets containing corn silage harvested at the medium chop length than the long chop length in experiment 2 . The reason for the difference is unknown. However, the authors speculate that there may have been a greater change in BW for cows fed diets containing medium chop length corn silage compared with long chop length corn silage in experiment 2.

Processing also had an effect on the difference between $\mathrm{NE}_{\mathrm{L}}$ intake and $\mathrm{NE}_{\mathrm{L}}$ required in experiment 1 (Table 19). There was a trend for a greater $(P<0.07)$ difference between $\mathrm{NE}_{\mathrm{L}}$ intake and $\mathrm{NE}_{\mathrm{L}}$ required when cows were fed diets that contained processed corn silage (experiment 1 ). The reason may be partially related to the greater energy density $\left(\mathrm{NE}_{\mathrm{L}} ; \mathrm{Mcal} / \mathrm{kg}\right)$ of processed corn silage-based diets compared to unprocessed corn silage-based diets that were consumed in experiment 1 (Table 18). However, there were no statistical differences between processed and unprocessed corn silagebased diets for the amount (Mcal/d) of $\mathrm{NE}_{\mathrm{L}}$ consumed or required in experiment 1 (Table 19).

Energy intake above maintenance was not different between treatments in experiment 1 (Table 19). However, in experiment 2 , energy intake above maintenance was significantly greater $(P<0.04)$ for cows fed the 
Table 18. Energy estimates of TMR fed to cows in experiments 1 and 2.

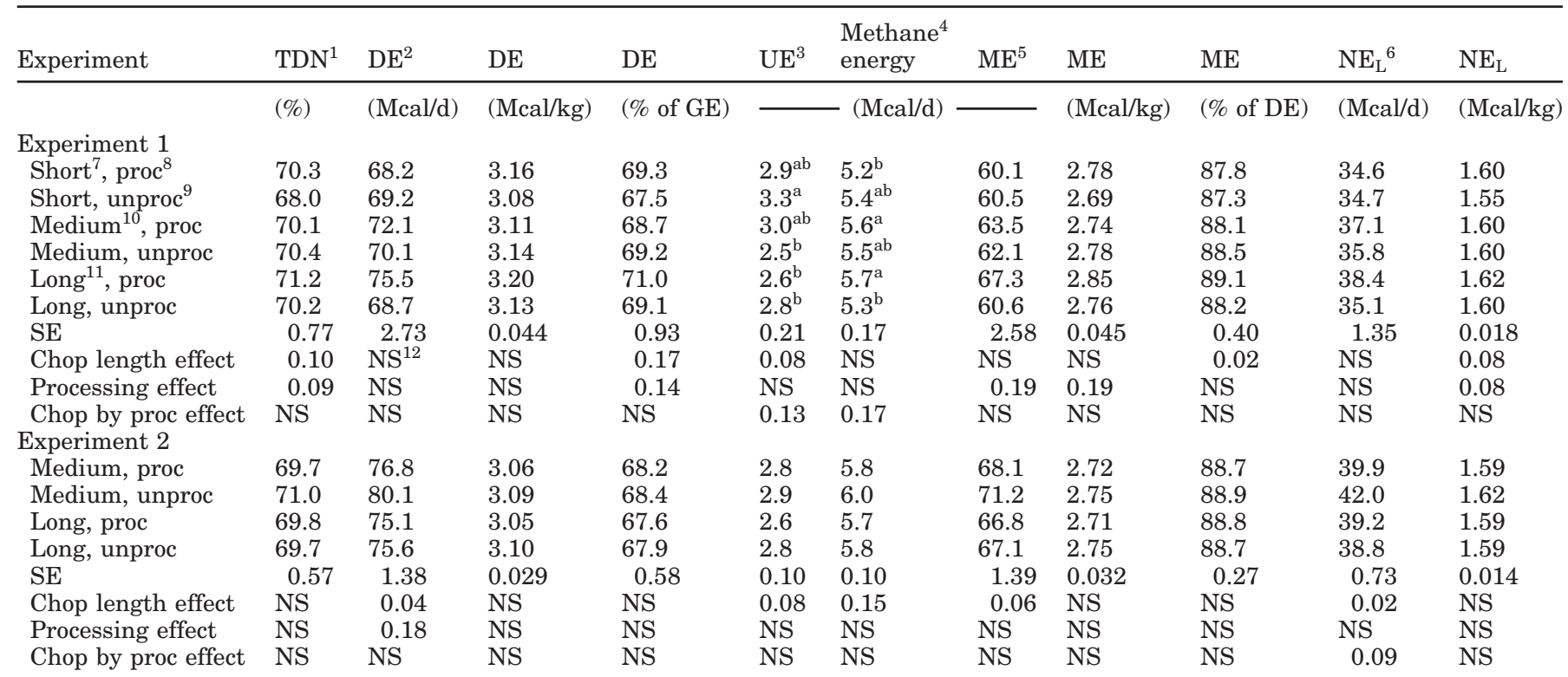

\footnotetext{
${ }^{1} \mathrm{TDN}-$ Total digestible nutrients. TDN $=$ digestible $\mathrm{CP}+$ digestible nonfiber carbohydrates + digestible NDF $+($ digestible fatty acids $\times$ $2.25)$.

${ }^{2} \mathrm{DE}$ - Digestible energy (Mcal/d, Mcal/kg DMI, and \%) was calculated from measured gross energy and fecal energy values collected during the digestion study.

${ }^{3}$ Urinary Energy - estimated from urinary nitrogen values [Urinary energy (Kcal/kg) $=23.8+(125.0 \times$ nitrogen $)$; Elliot and Loosli, 1959].

${ }^{4}$ Methane Energy - estimated from intake of carbohydrate fractions. Methane $(\mathrm{Mcal} / \mathrm{d})=0.814+[0.122 \times$ nonfiber carbohydrates $(\mathrm{kg} / \mathrm{d})]$ $+[0.415 \times$ hemicellulose $(\mathrm{kg} / \mathrm{d})]+[0.633 \times$ cellulose $(\mathrm{kg} / \mathrm{d})]$. Moe and Tyrell, 1979 .

${ }^{5} \mathrm{ME}$ - Metabolizable energy (Mcal/d, Mcal/kg DMI, and \%) estimated from GE, FE, urinary energy, and methane energy.

${ }^{6} \mathrm{NE}_{\mathrm{L}}-\mathrm{Net}$ energy of lactation (Mcal/d, Mcal/kg DMI) predicted from TDN (digestible $\mathrm{CP}+$ digestible nonfiber carbohydrates + digestible $\mathrm{NDF}+($ digestible fatty acids $\times 2.25)) . \mathrm{NE}_{\mathrm{L}}(\mathrm{Mcal} / \mathrm{kg})=(0.0245 \times \mathrm{TDN})-0.12$.

${ }^{7}$ Short - Corn silage was harvested at a TLC of $11.1 \mathrm{~mm}$.

${ }^{8}$ Proc - Corn silage was harvested with a 5830 John Deere harvester with kernel processing rolls set $1 \mathrm{~mm}$ apart.

${ }^{9}$ Unproc - Corn silage was harvested with a $5830 \mathrm{John}$ Deere harvester with kernel processing rolls set $15.9 \mathrm{~mm}$ apart.

${ }^{10}$ Medium - Corn silage was harvested at a TLC of $27.8 \mathrm{~mm}$.

${ }^{11}$ Long - Corn silage was harvested at a TLC of $39.7 \mathrm{~mm}$.

${ }^{12} \mathrm{NS}-P>0.10$.
}

medium chop length corn silage compared with the long chop length corn silage. There was a chop length $x$ processing interaction, and there was a trend for greater $(P<0.09)$ energy intake above maintenance for cows fed diets containing unprocessed medium chop length corn silage compared to the other treatments. The greater energy intake over maintenance was mainly due to the trend for greater DMI $(P<0.11)$ because $\mathrm{NE}_{\mathrm{L}}$ concentrations (Table 18) were not statistically different between treatments in experiment 2 .

\section{Performance Characteristics}

Performance characteristics were reported in Table 12. However, these data should be interpreted with caution because the experiments were short-term feeding trials. In experiment 1 , chop length and processing method of corn silage present in the diet did not have a significant effect on BW, milk, fat or protein production, fat or protein concentration, or MUN levels (Table 12). However, in experiment 2 , cows fed diets containing long chop corn silage had greater fat-corrected milk ( $P$ $<0.08)$, fat concentration $(P<0.06)$, fat production $(P$ $<0.03)$, and total milk nitrogen concentration $(P<0.12)$ than cows fed TMR containing corn silage harvested at a medium chop length (Table 12). In experiment 2, there was a chop length $\times$ processing interaction for fat production $(P<0.08$; Table 12). Therefore, the significant chop length effect was mainly due to the greater milk fat concentration and production for cows fed the diet containing long chop unprocessed corn silage compared with the other treatments (Table 12). The greater milk fat concentration and production for the long chop unprocessed corn silage diet may be partially explained by the greater percentage of corn silage particles remaining on the top layer of NASCO's Penn State Forage 
Table 19. Estimates of energy requirements based on milk production and maintenance in experiments 1 and 2.

\begin{tabular}{|c|c|c|c|c|c|}
\hline Experiment & $\begin{array}{l}\text { Energy intake } \\
\text { above main. }\end{array}$ & $\begin{array}{l}\mathrm{DE} \text { milk }{ }^{2} \\
+ \text { maintenance }\end{array}$ & $\begin{array}{l}\text { DE intake } \\
\text {-required }\end{array}$ & $\begin{array}{l}\mathrm{NE}_{\mathrm{L}} \text { milk }^{3} \\
+ \text { maintenance }\end{array}$ & $\begin{array}{l}\mathrm{NE}_{\mathrm{L}} \text { intake } \\
\text {-required }\end{array}$ \\
\hline & & & - $(\mathrm{M}$ & $\mathrm{l} / \mathrm{d})$ & \\
\hline \multicolumn{6}{|l|}{ Experiment 1} \\
\hline Short ${ }^{4}$, proc $^{5}$ & 3.3 & 54.1 & 14.1 & 28.2 & 6.4 \\
\hline Short, unproc ${ }^{6}$ & 3.2 & 56.8 & 18.4 & 29.8 & 4.9 \\
\hline Medium $^{7}$, proc & 3.5 & 54.3 & 18.0 & 28.4 & 8.7 \\
\hline Medium, unproc & 3.3 & 54.5 & 15.2 & 28.5 & 7.2 \\
\hline Long $^{8}$, proc & 3.6 & 55.6 & 19.9 & 29.3 & 9.1 \\
\hline Long, unproc & 3.3 & 56.7 & 15.1 & 29.5 & 5.6 \\
\hline $\mathrm{SE}$ & 0.12 & 2.63 & 3.61 & 1.35 & 1.49 \\
\hline Chop length effect & 0.14 & $\mathrm{NS}^{9}$ & NS & NS & NS \\
\hline Processing effect & 0.13 & NS & NS & NS & 0.07 \\
\hline Chop by proc effect & NS & NS & NS & NS & NS \\
\hline \multicolumn{6}{|l|}{ Experiment 2} \\
\hline Medium, proc & $3.8^{\mathrm{a}}$ & 68.4 & 9.7 & 35.7 & $4.2^{\mathrm{a}}$ \\
\hline Medium, unproc & $4.0^{\mathrm{b}}$ & 66.9 & 13.3 & 35.1 & $6.9^{\mathrm{b}}$ \\
\hline Long, proc & $3.8^{\mathrm{a}}$ & 68.7 & 8.1 & 35.7 & $3.5^{\mathrm{a}}$ \\
\hline Long, unproc & $3.8^{\mathrm{a}}$ & 71.6 & 7.7 & 37.1 & $1.7^{\mathrm{a}}$ \\
\hline $\mathrm{SE}$ & 0.07 & 1.44 & 1.89 & 0.72 & 1.05 \\
\hline Chop length effect & 0.04 & 0.09 & 0.07 & NS & 0.01 \\
\hline Processing effect & NS & NS & $\mathrm{NS}$ & NS & NS \\
\hline Chop by proc effect & 0.09 & 0.15 & NS & 0.19 & 0.05 \\
\hline
\end{tabular}

${ }^{1}$ Energy intake above main - Energy intake above maintenance $\left[\mathrm{NE}_{\mathrm{L}}\right.$ Intake $(\mathrm{Mcal} / \mathrm{d}) / \mathrm{NE}_{\mathrm{L}}$ Required for Maintenance (Mcal/d)].

${ }^{2} \mathrm{DE}$ Milk = digestible energy required to produce milk: $[\mathrm{DE}$ Milk $(\mathrm{Mcal} / \mathrm{d})=1.42 \times 4 \% \mathrm{FCM}(\mathrm{kg} / \mathrm{d})]$. NRC, (1989).

$\mathrm{DE}$ Maintenance $=$ digestible energy required for maintenance: $\left[\mathrm{DE}\right.$ Maintencance $(\mathrm{Mcal} / \mathrm{d})=0.155 \times \mathrm{BW}^{0.75}$ (kg/d)]. NRC, (1989).

${ }^{3} \mathrm{NE}_{\mathrm{L}}$ Milk $=\mathrm{NE}_{\mathrm{L}}$ required to produce milk: $\mathrm{NE}_{\mathrm{L}}$ Milk $(\mathrm{Mcal} / \mathrm{d})=[9.23 \times$ milk fat production $(\mathrm{kg} / \mathrm{d})]+[5.71$ $\times$ milk protein production $(\mathrm{kg} / \mathrm{d})]+[3.95 \times$ lactose production $(\mathrm{kg} / \mathrm{d})]$. Mertens and Dado, $(1993)$.

$\mathrm{NE}_{\mathrm{L}}$ Maintenance $=\mathrm{NE}_{\mathrm{L}}$ required for maintenance: $\left[\mathrm{NE}_{\mathrm{L}} \mathrm{BW}(\mathrm{Mcal} / \mathrm{d})=0.08 \times \mathrm{BW}^{0.75}(\mathrm{~kg} / \mathrm{d})\right] \mathrm{NRC},(1989)$.

${ }^{4}$ Short - Corn silage was harvested at a TLC of $11.1 \mathrm{~mm}$.

${ }^{5}$ Proc - Corn silage was harvested with a 5830 John Deere harvester with kernel processing rolls set 1 mm apart.

${ }^{6}$ Unproc - Corn silage was harvested with a 5830 John Deere harvester with kernel processing rolls set $15.9 \mathrm{~mm}$ apart.

${ }^{7}$ Medium - Corn silage was harvested at a TLC of $27.8 \mathrm{~mm}$.

${ }^{8}$ Long - Corn silage was harvested at a TLC of $39.7 \mathrm{~mm}$.

${ }^{9} \mathrm{NS}-P>0.10$.

Particle Separator in experiment 2 (Table 7). This is an indication that there was more effective fiber in the long chop unprocessed corn silage based diet which may have led to the higher milk fat concentration and production (experiment 2; Table 12). Also, in experiment 2 , cows fed the diet containing long chop corn silage tended to have lower BW $(P<0.03)$ and lower MUN concentrations $(P<0.12)$ than cows fed diet containing corn silage harvested at a medium chop length (Table 12). The trend for greater milk total $\mathrm{N}$ and lower MUN suggests there were more carbohydrates available for microbial $\mathrm{N}$ production because there was less ammonia being absorbed, converted to urea, and secreted in the milk (experiment 2).

Processing corn silage also affected performance characteristics in this study. In experiment 2 , cows fed diets containing processed corn silage had reduced milk protein concentration $(P<0.07)$, total milk $\mathrm{N}$ concentration $(P<0.07)$, and milk casein concentration $(P<0.05$; Table 12). In experiment 1 , the opposite trend occurred for total milk $\mathrm{N}$ and milk casein concentrations (Table 12). Cows fed diets containing processed corn silage had greater total milk $\mathrm{N}$ concentrations $(P<0.13)$ and milk casein concentrations $(P<0.12)$ than cows fed unprocessed corn silage diets (Table 12). Others have reported no change in milk protein and casein concentrations when diets containing processed corn silage were fed (Bal et al., 2000; Dhiman et al., 2000; Weiss and Wyatt, 2000; Johnson et al., 2002c).

In experiment 1 , milk fat concentration averaged $3.5 \%$, and milk protein concentration averaged $3.17 \%$ (Table 12). However, in experiment 2, milk fat concentration averaged $3.3 \%$, and milk protein concentration averaged $2.98 \%$ (Table 12). This was an indication that 
Table 20. DM recovery and pack density of corn silage stored in $122-\mathrm{cm}$ high $\times 122$-cm diameter silos in experiments 1 and 2 .

\begin{tabular}{|c|c|c|c|c|c|}
\hline Experiment & $\begin{array}{l}\text { Wet pack } \\
\text { density }\end{array}$ & $\begin{array}{l}\text { Dry pack } \\
\text { density }\end{array}$ & $\begin{array}{l}\text { Dry } \\
\text { spoilage }\end{array}$ & $\begin{array}{l}\mathrm{DM} \\
\text { recovery }\end{array}$ & $\begin{array}{l}\mathrm{DM} \\
\text { feedable }^{2}\end{array}$ \\
\hline & \multicolumn{2}{|c|}{$\left(\mathrm{kg} / \mathrm{m}^{3}\right)$} & (percentage of & 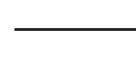 & \\
\hline \multicolumn{6}{|l|}{ Experiment 1} \\
\hline Short $^{3}$ proc $^{4}$ & $512^{\mathrm{ab}}$ & 165 & 0.0 & 93.0 & 93.0 \\
\hline Short, unproc ${ }^{5}$ & $530^{\mathrm{a}}$ & 166 & 0.13 & 95.6 & 95.4 \\
\hline Medium $^{6}$, proc & $507^{\mathrm{ab}}$ & 166 & 0.24 & 90.0 & 89.8 \\
\hline Medium, unproc & $496^{\mathrm{b}}$ & 159 & 0.0 & 94.7 & 94.7 \\
\hline Long ${ }^{7}$, proc & $505^{\mathrm{a}}$ & 160 & 0.0 & 94.9 & 94.9 \\
\hline Long, unproc & $464^{\mathrm{c}}$ & 152 & 0.10 & 93.1 & 93.0 \\
\hline $\mathrm{SE}$ & 12.3 & 4.8 & 0.118 & 2.98 & 3.0 \\
\hline Chop length effect & 0.02 & 0.12 & NS & NS & NS \\
\hline Processing effect & $\mathrm{NS}^{8}$ & NS & NS & NS & NS \\
\hline Chop by proc effect & 0.06 & NS & NS & NS & NS \\
\hline \multicolumn{6}{|l|}{ Experiment 2} \\
\hline Medium, proc & 474 & 179 & 4.05 & $94.6^{\mathrm{ab}}$ & $91.0^{\mathrm{b}}$ \\
\hline Medium, unproc & 485 & 178 & 4.72 & $95.8^{\mathrm{ab}}$ & $91.3^{\mathrm{b}}$ \\
\hline Long, proc & 447 & 173 & 0.67 & $97.0^{\mathrm{a}}$ & $96.4^{\mathrm{a}}$ \\
\hline Long, unproc & 445 & 167 & 2.99 & $94.1^{\mathrm{b}}$ & $91.3^{\mathrm{b}}$ \\
\hline $\mathrm{SE}$ & 8.5 & 3.3 & 1.41 & 1.20 & 1.44 \\
\hline Chop length effect & 0.0004 & 0.01 & 0.08 & NS & 0.06 \\
\hline Processing effect & NS & NS & NS & NS & 0.08 \\
\hline Chop by proc effect & NS & NS & NS & 0.08 & 0.05 \\
\hline
\end{tabular}

${ }^{1} \mathrm{DM}$ recovery - The total amount of dry corn silage (silage + spoilage) that was removed from the silo.

${ }^{2} \mathrm{DM}$ feedable - The total amount of dry corn silage (silage - spoilage) removed from the silo that was feedable.

${ }^{3}$ Short - Corn silage was harvested at a TLC of $11.1 \mathrm{~mm}$.

${ }^{4}$ Proc - Corn silage was harvested with a 5830 John Deere harvester with kernel processing rolls set 1 mm apart.

${ }^{5}$ Unproc - Corn silage was harvested with a $5830 \mathrm{John}$ Deere harvester with kernel processing rolls set $15.9 \mathrm{~mm}$ apart.

${ }^{6}$ Medium - Corn silage was harvested at a TLC of $27.8 \mathrm{~mm}$.

${ }^{7}$ Long - Corn silage was harvested at a TLC of $39.7 \mathrm{~mm}$.

${ }^{8} \mathrm{NS}-P>0.10$.

the starch and fiber levels of the total diet were not balanced properly. In experiment 1 , cows were almost $100 \mathrm{~d}$ further into lactation than cows in experiment 2 . Therefore, the cows in experiment 1 weighed approximately 20 to $25 \mathrm{~kg}$ more than cows in experiment 2 . Starch consumed, as a percentage of DMI, was between 27 and 28\% (Table 5); NDF intake (\% of BW) was between 1.12 and $1.21 \%$, and forage NDF intake (\% of BW) was between 0.61 to $0.65 \%$ for cows in experiment 1 (Table 11). Starch consumed, as a percentage of DMI, was between 29 and $32 \%$ (Table 6), NDF intake (percentage of BW) was $\sim 1.3 \%$, and forage NDF intake (percentage of BW) was between 0.71 and $0.75 \%$ for cows in experiment 2 (Table 11).

Recommendations indicate that forage NDF intake (percentage of BW) should be $0.75 \%$ if NDF intake as a percentage of BW is $1.3 \%$ (Varga et al., 1998). Therefore, it would appear that cows in experiment $2 \mathrm{had}$ enough forage in the diet to maintain milk fat and protein concentrations. However, milk fat and protein concentrations were low for cows in experiment 2 . In experiment 1, it would appear that cows did not have adequate NDF or forage NDF as a percentage of BW; however, milk fat and protein concentrations were comparatively higher. The difference in milk fat and protein concentrations between experiments may have been related to stage of lactation. In experiment 2 , the low fat and protein concentrations were partially related to cows being in early lactation (128 vs. 217 DIM), having higher milk production $(\sim 10 \mathrm{~kg} / \mathrm{d}$ more $)$, and a greater starch intake (percentage of DMI, 2.7 percentage units) compared with cows in experiment 1 . These results indicate that although it appears that forage levels in the diet are adequate, it is also important to evaluate stage of lactation, level of starch in the diet, particle size of the forage, and BW of the animal.

\section{Pack Density and DM Recovery}

Wet and dry pack density measurements and DM recovery of corn silage were reported in Table 20. In both experiments, pack density was affected by chop 
length of the corn silage. In experiment 1 , wet $(P<0.02)$ and dry $(P<0.12)$ pack density were lower for corn silage harvested at a long chop length compared to corn silage harvested at a short chop length (Table 20). In experiment 2, corn silage harvested at a long chop length had lower wet $(P<0.0004)$ and dry $(P<0.01)$ pack density measurements than corn silage harvested at a medium chop length (Table 20).

Dry matter recovery of corn silage was high in both experiments (>90\%; Table 20 ). In experiment $1, \mathrm{DM}$ recovery and feedable DM (calculation doesn't include spoilage) were not significantly affected by chop length or processing method of corn silage (Table 20). However, in experiment 2 , feedable DM $(P<0.05)$ was greater for the long chop processed corn silage compared with the long chop unprocessed and medium chop processed and unprocessed corn silage. Hybrid 3845 (experiment 1) tended to have a lower amount of spoilage than hybrid Quanta (experiment 2; Table 20). This was similar to trends observed by others (Johnson et al., 2002a) who reported that hybrid 3845 tended to have a lower amount of spoilage than hybrid Quanta. These results suggest that more air may be able to penetrate the exposed silage face of hybrid Quanta corn silage than hybrid 3845 corn silage.

\section{CONCLUSIONS}

Pack density of corn silage was lower at the longer chop lengths in both experiments. The ALC and the percentage of particles $>19 \mathrm{~mm}$ for corn silage increased as the TLC increased from 11.1 to $39.7 \mathrm{~mm}$ in experiment 1, and from 27.8 to $39.7 \mathrm{~mm}$ in experiment 2 . In experiment 1 , apparent total tract DM, $\mathrm{OM}$, and NDF digestibilities were lower for cows fed diets containing corn silage harvested at a short chop length $(11.1 \mathrm{~mm})$ compared with corn silage harvested at a long chop length $(39.7 \mathrm{~mm})$. The lower total tract digestibility of nutrients may have contributed to the lower TDN, ME (percentage of digestible energy), and $\mathrm{NE}_{\mathrm{L}}$ concentration of diets containing the short chop length corn silage (experiment 1 ). In experiment 2 , total tract starch digestibility was greater for cows fed medium chop $(27.8 \mathrm{~mm})$ corn silage diets, and total tract NDF digestibility was greater for cows fed long chop $(39.7 \mathrm{~mm})$ corn silage diets. The opposing effect of total tract starch and fiber digestibilities between chop lengths may have contributed to the lack of difference in energy content of the diets in experiment 2 .

Mechanical processing tended to reduce particle size of corn silage. TDN and $\mathrm{NE}_{\mathrm{L}}$ concentrations of the processed corn silage diets were greater than the unprocessed corn silage diets in experiment 1 . The increase in energy concentration for the processed corn silage diet was due to greater total tract digestibility of $\mathrm{OM}$ and ether extract. Total tract starch digestibility was greater and total tract NDF digestibility was lower for cows fed processed corn silage diets compared to unprocessed corn silage diets in experiment 2. The opposing effect of total tract starch and fiber digestibilities between processed and unprocessed corn silage may have contributed to the lack of difference in energy content of the diets in experiment 2. Mechanical processing also altered ruminal VFA concentrations in experiment 2. There was a decrease in the acetate concentration and the acetateto-propionate ratio and an increase in the propionate concentration in the rumen when processed corn silage was fed instead of unprocessed corn silage.

The results from this study suggest that there will be an improvement in the energy concentration of the diet when the total tract digestibility of nutrients consistently increase for a treatment. However, if there is an opposing effect of starch and fiber digestibilities, there tends to be no difference in the energy concentrations between treatments.

\section{REFERENCES}

Aldrich, J. M., L. D. Muller, G. A. Varga, and L. C. Griel, Jr. 1993. Nonstructural carbohydrate and protein effects on rumen fermentation, nutrient flow, and performance of dairy cows. J. Dairy Sci. 76:1091-1105.

Andrae, J. G., C. W. Hunt, G. T. Pritchard, L. R. Kennington, J. H. Harrison, W. Kezar, and W. Mahanna. 2001. Effects of hybrid, maturity, and mechanical processing of corn silage on intake and digestibility by beef cattle. J. ANim. Sci. 79:2268-2275.

Association of Official Analytical Chemists. 1990. Official Methods of Analysis. 15th ed. AOAC, Arlington, VA.

Bal, M. A., R. D. Shaver, A. G. Jirovec, K. J. Shinners, and J. G. Coors. 2000. Crop processing and chop length of corn silage: effects on intake, digestion, and milk production by dairy cows. J. Dairy Sci. 83:1264-1273.

Clark, P. W., and L. E. Armentano. 1999. Influence of particle size on the effectiveness of the fiber in corn silage. J. Dairy Sci. 82:581-588

Dhiman, T. R., M. A. Bal, Z. Wu, V. R. Moreira, R. D. Shaver, L. D. Satter, K. J. Shinners, and R. P. Walgenbach. 2000. Influence of mechanical processing on utilization of corn silage by lactating dairy cows. J. Dairy Sci. 83:2521-2528.

Doggett, C. G. 1998. Evaluation of the effect of corn hybrid and processing on digestion of whole plant silage, grain, and stover. MS Thesis, Univ. Idaho, Moscow, Idaho.

Elliot, J. M., and J. K. Loosli. 1959. Effect of the dietary ratio of hay to concentrate on milk production, ration digestibility, and urinary energy losses. J. Dairy Sci. 42:836-842.

Fassel, V.A. 1978. Quantitative elemental analyses by plasma emission spectrophotometry. Science 202:183-191.

Goering, H. K., and P. J. Van Soest, 1970. Forage Fiber Analyses (Apparatus, Reagents, Procedures, and Some Applications). Agric. Handbook No. 379. ARS-USDA, Washington, DC.

Holm, J. I. Björck, A. Drews, and N.-G. Asp. 1986. A rapid method for the analysis of starch. Starch/Stärke 38:7:224-226.

Johnson, L M., J. H. Harrison, D. Davidson, J. Robutti, M. Swift, B. Mahanna, and K. Shinners. 2002a. Corn silage management I: effects of hybrid, maturity, and mechanical processing on chemical and physical characteristics. J. Dairy Sci. 85:833-853. 
Johnson, L. M., J. H. Harrison, D. Davidson, M. Swift, B. Mahanna, K. Shinners. 2002b. Corn silage management II: effects of hybrid, maturity, and mechanical processing on digestion and energy content. J. Dairy Sci. 85:2913-2927.

Johnson, L. M., J. H. Harrison, D. Davidson, M. Swift, B. Mahanna, and K. Shinners. 2002c. Corn silage management III: effects of hybrid, maturity, and mechanical processing on nitrogen metabolism and ruminal fermentation. J. Dairy Sci. 85:2928-2947.

Kotarski, S. F., R. D. Waniska, and K. K. Thurn. 1992. Starch hydrolysis by the ruminal microflora. J. Nutr. 122:178-190.

Mertens, D. R., and R. G. Dado. 1993. System of equations for fulfilling net energy and absorbed protein requirements for milk component production. J. Dairy Sci. 76:3464-3478.

Moe, P. W., and H. F. Tyrrell. 1979. Methane production in dairy cows. J. Dairy Sci. 62:1583-1586.

National Research Council. 1989. Nutrient Requirements of Dairy Cattle. 6th rev. ed. Natl. Acad. Sci., Washington, DC.

Roberge, M., P. Savoie, and E. Norris. 1998. Evaluation of a crop processor in a pull-type forage harvester. Transactions of the American Society of Agricultural Engineers 41(4):967-972.

Rojas-Bourrillon, A., J. R. Russel, A. Trenkle, and A. D. McGillard. 1987. Effects of rolling on the composition and utilization by growing steers of whole-plant corn silage. J. Anim. Sci. 64:303-311.

Schurig, M., and G. Rodel. 1993. Power consumption and the effect of corncrackers. ASAE paper no. 931586. American Society of Agricultural Engineers, St. Joseph, MI.
SAS User's Guide: Statistics, Version 6.03 Edition. 1988. SAS Inst., Inc., Cary, NC.

Stockdale, C. R., and G. W. Beavis. 1994. Nutritional evaluation of whole plant maize ensiled at three chop lengths and fed to lactating dairy cows. Aust. J. Exp. Agric. 34:709-716.

Van Soest, P. J., J. B. Roberston, and B. A. Lewis. 1991. Methods for dietary fiber, neutral detergent fiber, and nonstarch polysaccharides in relation to animal nutrition. J. Dairy Sci. 74:3583-3597.

Varga, G. A., H. M. Dann, and V. A. Ishler. 1998. The use of fiber concentrations for ration formulation. J. Dairy Sci. 81:30633074.

Weigand, E., U. Meyer, and N. Guth. 1993. Intake, chewing activity, and carbohydrate digestibility by lactating dairy cows fed maize silage with a different physical structure. J. Anim. Phys. Anim. Nutr. 69:120-132.

Weiss, W. P., and D. J. Wyatt. 2000. Effect of oil content and kernel processing of corn silage on digestibility and milk production by dairy cows. J. Dairy Sci. 83:351-358.

Williams, C. H., D. J. David, and O. Iismaa. 1962. The determination of chromic oxide in fecal samples by atomic absorption spectrophotometry. J. Agri. Sci. (Camb.) 59:381-385.

Zinn, R. A., and F. N. Owens. 1986. A rapid procedure for purine measurement and its use for estimating net ruminal protein synthesis. Can. J. Anim. Sci. 66:157-166. 